\author{
Michał Norbert Faszcza \\ (Akademia Humanistyczna im. A. Gieysztora w Pułtusku)
}

\title{
Wyobrażenia późnorepublikańskich centurionów i ich znaczenie dla badań nad wojskowością rzymską w I w. przed Chr.
}

\author{
Depictions of the Late Republican centurions and their meaning \\ for the study on the Roman army of the 1st B.C.
}

\begin{abstract}
STRESZCZENIE:
Współcześni badacze republikańskiej wojskowości rzymskiej zazwyczaj pomijają tematykę centurionów, co sprawia, że jest to jedyna kategoria wchodząca w skład ówczesnej kadry dowódczej, która nie doczekała się odrębnego studium. Liczne wzmianki zawarte na jej temat w zachowanych przekazach źródłowych zdaniem autora mogą być z powodzeniem uzupełnione przez źródła wizualne pod postacią płaskorzeźb. Jakkolwiek ich liczba w odniesieniu do czasów sprzed I w. po Chr. jest stosunkowo nieliczna, to dostarczają one informacji o unikatowym charakterze, których próżno szukać w antycznej literaturze. Wszystkie znane wyobrażenia republikańskich centurionów odnoszą się do I w. przed Chr., co koresponduje ze wzrostem ich znaczenia militarnego i społeczno-ekonomicznego w tym okresie, a jednocześnie w przypadku przedstawień nagrobnych dowodzi definiowania się weteranów przez pryzmat roli pełnionej w legionach. Co ciekawe, takie zjawisko cechowało u schyłku republiki wyłącznie centurionów, co stanowi potwierdzenie opinii o ich elitarnym statusie w ówczesnej armii rzymskiej.
\end{abstract}

Słowa kluczowe: armia rzymska, centurionowie, reliefy, późna republika rzymska

Choć każdego roku ukazuje się znaczna liczba publikacji poświęconych armii rzymskiej, to wiele kluczowych tematów w dalszym ciągu pozostaje nieopracowanych. Niewątpliwie przyczyniła się do tego nasilająca się na Zachodzie tendencja do pomniejszania rangi badań nad antyczną wojskowością i sukcesywne spychanie historyków wojskowości na margines życia naukowego. W efekcie o rzymskich siłach zbrojnych pisze się 
albo w kontekście ich funkcjonowania społecznego, albo w ramach badań nad psychologicznymi uwarunkowaniami walki, albo też w sposób przeznaczony dla szerokiego grona czytelników (zazwyczaj ze szkodą dla poziomu merytorycznego). Potwierdzeniem kryzysu, który dotknął „klasyczne" badanie wojskowości, może być wydana niedawno książka autorstwa Dextera Hoyosa, poświęcona wojnom punickim ${ }^{1}$, która w porównaniu z opracowaniem Christelle Fischer-Bovet na temat związków armii i społeczeństwa w ptolemejskim Egipcie $^{2}$ zdaje się tylko dostarczać argumentów przeciwnikom tradycyjnego ujmowania historii wojskowości. Przykład Nicholasa Sekundy pokazuje jednak, że przy zastosowaniu odpowiedniej metodologii takie badania $\mathrm{w}$ dalszym ciągu potrafią być niezmiernie ożywcze, bez konieczności wpasowywania się w modne nurty $^{3}$. Wymaga to jednak umiejętnego zestawienia przekazów źródłowych, inskrypcji, płaskorzeźb, malowideł naściennych oraz znalezisk archeologicznych innego typu (głównie elementów ekwipunku).

Największy kryzys dotknął prawdopodobnie środowisko zajmujące się armią republikańskiego Rzymu. Nie tylko bowiem doszło do zahamowania rozwoju prowadzonych do tej pory badań, ale można nawet zaobserwować powstanie zjawiska polegającego na lekceważeniu dorob$\mathrm{ku}$ naukowego poprzednich pokoleń, co skutkuje rozpowszechnianiem tez, które nieco ironicznie mogą być określone jako „przednaukowe" Brakuje refleksji nad kształtowaniem się relacji między wodzami a obywatelami-żołnierzami, które wykraczałyby poza uproszczoną wizję klienteli politycznej, dyscyplina, a nawet - co najbardziej zaskakujące - ewolucją korpusu centurionów. Ci ostatni pojawiają się bowiem w przekazach

${ }^{1}$ D. Hoyos, Mastering the West. Rome and Carthage at War, Oxford 2015. Dość powiedzieć, że Hoyos ma nawet poważny problem $\mathrm{z}$ prawidłowym odtworzeniem struktury armii rzymskiej w tym okresie, a przecież cieszy się opinią jednego z najlepszych współczesnych znawców wojen punickich! Por. wiekowy już, ale w zaskakujący sposób nieuwzględniany artykuł na temat interpretacji źródeł odnoszących się do ówczesnej armii rzymskiej: E. Rawson, The Literary Sources for the Pre-Marian Army, "Papers of the British School at Rome" 1971, t. 39, s. 1331.

${ }^{2}$ Ch. Fischer-Bovet, Army and Society in Ptolemaic Egypt, Cambridge 2014.

${ }^{3}$ Najlepszym tego przykładem jest książka: N. Sekunda, Hellenistic Infantry Reform in the 160's BC, Łódź 2001, wprost modelowo ukazująca w jaki sposób powinno się badać antyczną wojskowość.

${ }^{4}$ Dotyczy to np. cieszących się ogromną popularnością przekrojowych prac skądinąd utytułowanego historyka, jakim jest Adrian K. Goldsworthy: Roman Warfare, London 2000; The Complete Roman Army, London 2003. Znacznie bardziej bolesne jest jednak powtarzanie ich w książce, która w założeniu miała stanowić podsumowanie dotychczas prowadzonych badań i stworzyć nowe impulsy do podjęcia pogłębionych studiów: A Companion to the Roman Army, red. P. Erdkamp, Malden-Oxford-Carlton 2007 (wystarczy porównać poziom rozdziału napisanego przez Johna $W$. Richa z na wskroś anachronicznymi wynurzeniami Hoyosa czy Pierre'a Cagniarta). 
źródłowych na tyle często, że stanowią wdzięczny materiał o charakterze anegdotycznym, co z dobrym skutkiem wykorzystał np. Ross Cowan ${ }^{5}$. Czym innym jest jednak przytaczanie bardziej interesujących wątków z ich udziałem, a czym innym poddanie ich działalności wyczerpującej analizie przy wykorzystaniu wszelkich dostępnych kategorii źródeł. W sposób zupełnie niezrozumiały republikańskim centurionom nie poświęcono do tej pory żadnej monografii, choć uczyniono to w odniesieniu do trybunów, legatów i prefektów ${ }^{6}$, nie wspominając o głównodowodzących ${ }^{7}$. Rozważania na ich temat pojawiają się przy okazji opisywania innych zagadnień, a zatem - zważywszy na znaczenie centurionów w rzymskich siłach zbrojnych - mamy do czynienia z luką która wymaga wypełnienia.

Celem niniejszego artykułu jest przedstawienie zachowanych wyobrażeń republikańskich centurionów zarówno w kontekście militarnym, jak i społeczno-ekonomicznym. Wszystkie z nich odnoszą się do I w. ${ }^{8}$, co już samo w sobie jest niezwykle znamienne9. Przedstawienia te stanowią cenne uzupełnienie źródeł literackich, niejednokrotnie wzbogacając je o nowe ustalenia. Tymczasem sposób wizualnego przedstawiania centurionów do tej pory wzbudził zainteresowanie wyłącznie Raffaele'a D'Amato, choć obie jego publikacje poświęcone temu zagadnieniu, z uwagi na niewielką objętość, noszą raczej przyczynkarski charakter ${ }^{10}$. Nie sposób mu jednak odmówić autorstwa wielu inspirujących inter-

${ }^{5}$ R. Cowan, For the Glory of Rome. A History of Warriors and Warfare, London 2007, s. 184-206. Polskojęzyczny przekład wspomnianej książki (Wojny, bitwy i wojownicy rzymscy, przeł. E. Westwalewicz-Mogilska, Warszawa 2010) znajduje się na skandalicznie niskim poziomie i aż dziw, że w ogóle został dopuszczony do druku.

${ }^{6}$ J. Suolahti, The Junior Officers of the Roman Army in the Republican Period. A Study on Social Structure, Helsinki 1955.

${ }^{7}$ Przykładowo: A. M. Eckstein, Senate and General: Individual Decision-making and Roman Foreign Relations, 264-194 B.C., Berkeley-Los Angeles 1987; N. S. Rosenstein, Imperatores Victi: Military Defeat and Aristocractic Competition in the Middle and Late Republic, Berkeley-Los Angeles 1990; K. Resch, Die Freiheit des Feldherrn. Der Handlungsspielram römischer Feldherren, 218-133 v. Chr., Wien-Berlin 2010.

${ }^{8}$ Wszystkie daty zawarte $\mathrm{w}$ niniejszym artykule odnoszą się do czasów przed narodzeniem Chrystusa, chyba że wyraźnie zaznaczono inaczej.

${ }^{9}$ Całkowicie nie zgadzam się z interpretacją zakładająca, że jedna z postaci ukazanych na ścianie tzw. grobowca Scypionów (sepolcro degli Scipioni), pochodzącego z III w., jest centurionem. Miałby o tym rzekomo przesądzać trzymany przez nią kij, będący rózgą przeznaczoną do wymierzania żołnierzom kar cielesnych (R. D'Amato, Roman Centurions 753-31 BC. The Kingdom and the Age of Consuls, Oxford 2011, s. 13). Nie tylko nie mamy żadnej pewności co do tego, czym jest ów przedmiot, ale nic nie wskazuje nawet, że wspomniane postaci są żołnierzami. Jest to identyfikacja całkowicie arbitralna i mająca więcej wspólnego z myśleniem życzeniowym niż z rzetelną analizą problemu.

${ }^{10}$ R. D' Amato, Roman Centurions 753-31 BC...; idem, Roman Centurions 31 BC-AD 500. The Classical and Late Empire, Oxford 2012. 
pretacji, a nade wszystko zwrócenia uwagi na ten pomijany dotąd problem. Nawet Valerie M. Hope, która poświęciła cały artykuł znaczeniu przedstawień wizualnych dla badania dziejów wojskowości rzymskiej, niejako przeszła nad okresem republikańskim do porządku dziennego, wykorzystując jedynie odnoszące się do tego okresu przekazy źródłowe. Można nawet odnieść wrażenie, że „wizualna historia” armii rzymskiej zaczyna się dla niej od czasów panowania Augusta ${ }^{11}$. Z pewnością okres późnorepublikański nie dostarcza tylu artefaktów co późniejsze wieki, jednakże znacznie lepiej koresponduje z treścią zachowanych źródeł literackich, co pozwala na stosunkowo dokładne umocowanie ich w kontekście przemian zachodzących w ówczesnym społeczeństwie rzymskim.

Należy mieć przy tym świadomość ograniczeń związanych z przedmiotem prowadzonych badań. Przede wszystkim jest nim niewielka liczba zachowanych płaskorzeźb, którym nie zawsze towarzyszą inskrypcje. Do tej pory udało się odnaleźć zaledwie dwa nagrobki centurionów, co jest szczególnie dotkliwe, gdyż dostarczają one wielu unikatowych informacji. Co gorsza, oba pochodzą z północnej Italii i upamiętniają żołnierzy służących w armii tego samego wodza. Zawęża to w sposób znaczący perspektywę badawczą. Pozostałe wyobrażenia zostały umieszczone niejako przy okazji prezentacji innych scen, dzięki czemu możliwe jest jednak dokonanie porównania pomiędzy wizerunkami przedstawiającymi realnych centurionów (bez względu na schematyczność ich wykonania) a ich obrazem przeznaczonym dla szerszego grona odbiorców, nie zawsze mających za sobą służbę $\mathrm{w}$ armii. Z drugiej strony nie mówią one nic na temat wewnętrznej hierarchii panującej w obrębie korpusu centurionów, którą trzeba odtwarzać na podstawie innych typów źródeł ${ }^{12}$. Uniemożliwia to ewentualne powiązanie rang z elementami ekwipunku mogącymi stanowić ich wizualny wyznacznik, choć samo istnienie takiej zasady stoi pod poważnym znakiem zapytania.

Dodatkową trudnością jest rozstrzygnięcie, kiedy mamy do czynienia z centurionem, a kiedy z żołnierzem innego stopnia. Dokonanie poprawnej identyfikacji jest zasadniczym problemem, ponieważ pozwala na ustalenie, iloma przedstawieniami republikańskich centurionów $\mathrm{w}$ istocie

${ }^{11}$ V.M. Hope, Trophies and Tombstones: Commemorating the Roman Soldier, „World Archeology" 2003, t. 35, nr 1; The Social Commemoration of Warfare, s. 79-97.

${ }^{12}$ Zob. M. Radin, The Promotion of Centurions in Caesar's Army, "The Classical Journal" 1915, t. 10, nr 7, s. 300-311; H. M. D. Parker, A Note on the Promotion of the Centurions, "The Journal of Roman Studies" 1926, t. 16, s. 45-52; J. Harmand, L'armée et le soldat à Rome: de 107 à 50 avant notre ère, Paris 1967, s. 327-333; A. von Domaszewski, Die Rangordnung des Römischen Heeres, red. B. Dobson, Cologne 1967, s. 91, 93. 


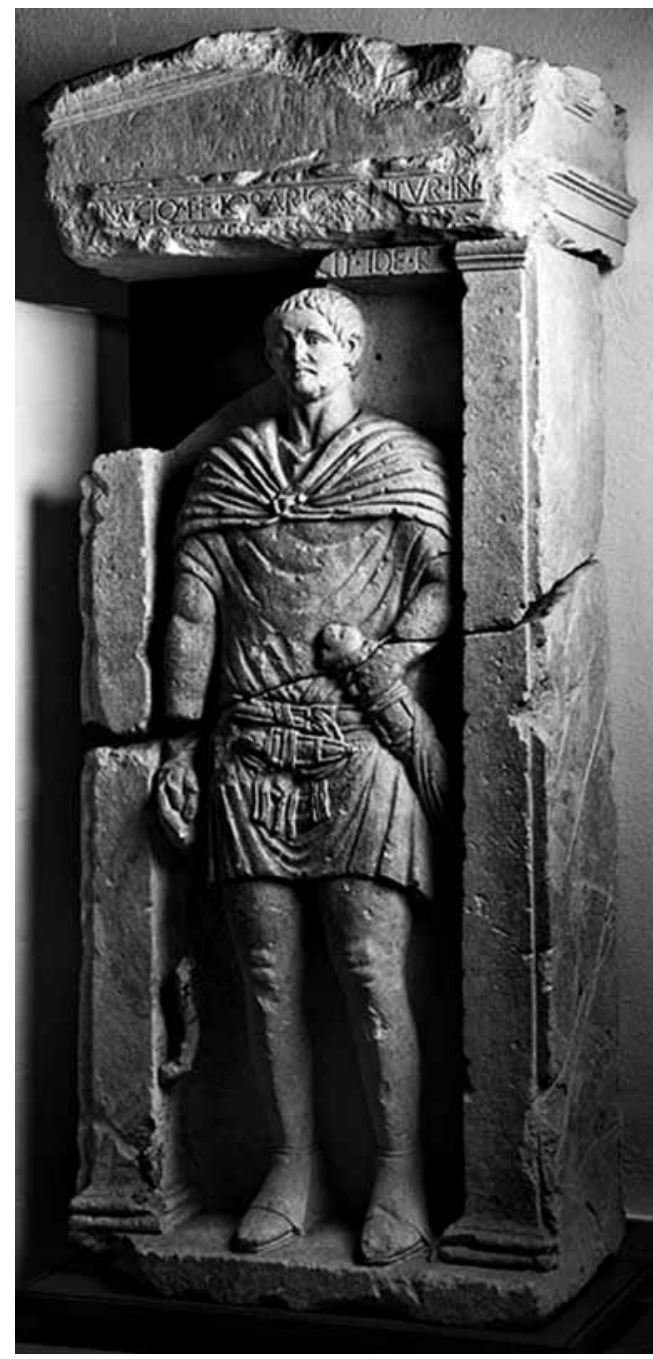

Ryc. 1. Płaskorzeźba nagrobna centuriona Minuciusa Lorariusa (ze zbiorów Museo Archeologico, Padwa; źródło: Europeana free commons) dysponujemy. Ułatwiają to pewne charakterystyczne szczegóły pojawiające się na płaskorzeźbach, którym nie należy jednak nadawać charakteru absolutnego już choćby $\mathrm{z}$ tego względu, że sporządzający je rzemieślnicy nie musieli mieć dokładnej wiedzy z zakresu militariów, a fundator niekoniecznie musiał przywiązywać wagę do detali.

Najbardziej znanym wyobrażeniem późnorepublikańskiego centuriona jest odnaleziona w 1963 r. płaskorzeźba nagrobna przedstawiająca Minuciusa Lorariusa (ryc. 1) służącego w legio Martia. Wspomniany nagrobek jest dość ogólnie datowany na panowanie Augusta - mógł on ewentualnie powstać nieco wcześniej, czyli pod koniec lat czterdziestych I w., kiedy legio Martia po raz ostatni pojawia się w źródłach $^{13}$. Pomimo że stan zachowania płaskorzeźby jest stosunkowo dobry, to $\mathrm{z}$ postacią Lorariusa wiąże się kilka problemów interpretacyjnych. Nie ulega natomiast wątpliwości, że mamy do czynienia z centurionem, na co wskazuja trzy elementy: miecz zawieszony $\mathrm{u}$ lewego boku ${ }^{14}$, wykonana $\mathrm{z}$ wi-

${ }^{13}$ L. Keppie, A centurion of legio Martia at Padova?, „Journal of Roman Military Equipment Studies" 1991, t. 2, s. 115, 119.

${ }^{14}$ B. Rankov, Military Forces, [w:] The Cambridge History of Greek and Roman Warfare, Vol. II. Rome from the Late Republic to the Late Empire, red. P. Sabin, H. van Wees, M. Whitby, Cambridge 2007, s. 59; R. D'Amato, Roman Centurions 753-31 BC..., s. 24; idem, Roman Centurions $31 B C-A D 500 \ldots$, s. 33. Pochodzące z okresu cesarstwa wyobrażenia centurionów jednoznacznie wskazuja, że w zakresie noszenia miecza istniała wyraźna różnica miedzy centurionami a żołnierzami niższymi rangą. Lawrence Keppie (op. cit., s. 115) stwierdził, że 
norośli rózga (vitis) ${ }^{15}$ oraz zachowany fragment inskrypcji, której początek przedstawia się w sposób następujący:

[M]invcio T(iti) f(ilio) Lorario c[e]ntvr(ioni) in 1[eg(ione)] / Martia ${ }^{16}$

Lorarius został ukazany w krótkiej tunice sięgającej do połowy uda, która zdaniem Kwintyliana (Marcus Fabius Quintilianus) była charakterystyczna właśnie dla centurionów ${ }^{17}$.

Pierwszą kwestią sporną jest status prawny Lorariusa. Legio Martia była bowiem jednostką złożoną z Italików, których rodziny nie uzyskały w 88 r. obywatelstwa rzymskiego ${ }^{18}$. Jako taka stanowiła legio vernacula ${ }^{19}$, co oczywiście nie powodowało, że pozostawała poza oficjalnymi strukturami militarnymi republiki. Legio Martia jest najbardziej znana z buntu, który wszczęła w 44 r. przeciwko Antoniuszowi (Marcus Antonius), w wyniku czego zasiliła następnie armię „,senacką" ${ }^{20}$. W momencie wstąpienia do wojska Lorarius nie posiadał zatem najprawdopodobniej obywatelstwa rzymskiego ${ }^{21}$. Niezachowany fragment inskrypcji, z uwa-

sztylet nie został przez Lorariusa przytroczony do prawego boku, aby było mu wygodniej używać rózgi.

${ }^{15}$ Zob. P. Cosme, La remise du cep de vigne au centurion, signe d'appartenance à une élite militaire, [w:] Actes du Colloque: Les élites et leurs facettes. Les élites locales dans le monde hellénistique et romain, red. M. Cébeillac-Gerrasoni, L. Lamoune, Rome-Clermont-Ferrand 2003, s. 339-348.

${ }^{16}$ AE 1982, 395.

${ }^{17}$ Quint., Inst., 11.138.

${ }^{18}$ App., BC, 3.69.283.

${ }^{19}$ J. Kromayer, G. Veith, Heerwesen und Kriegführung der Griechen und Römer, München 1928, s. 405; G. Forni, Il reclutamento delle legioni da Augusto a Diocleziano, Milano-Roma 1953, s. 52; J. Harmand, op. cit., s. 235-236, 240, 242, 431; L. Keppie, The Making of the Roman Army. From Republic to Empire, London 1984, s. 141.

${ }^{20}$ Cic., Phil., 3.6, 3.39, 4.5-6, 5.23, 10.21, 12.8, 13.19, 14.31; Liv., Per., 117; Vell. 2.61.2; App., BC, 3.45.185-187; Cass. Dio 45.13.3-4. Określenie "senacka” jest w tym przypadku umowne, albowiem środowiska polityczne pozostające w opozycji do Antoniusza nie opracowały nigdy jednolitej linii postępowania, niejednokrotnie występując przeciwko sobie. Dość powiedzieć, że w tym okresie współpracował z nimi nawet Cezar Młodszy (Caius Iulius Caesar), późniejszy cesarz August. Na temat skomplikowanej i labilnej sytuacji politycznej panującej w tym okresie: R. Syme, The Roman Revolution, Oxford 1939, s. 97-186; J. Osgood, Caesar's Legacy. Civil War and the Emergence of the Roman Empire, Cambridge 2008 , s. $12-61$.

${ }^{21} \mathrm{~W}$ tym kontekście można zadać pytanie o zasadność dokonywanych przez Keppiego (A centurion of..., s. 116, 118-119) prób przyporządkowania legio Martia do któregoś z legionów Cezara, wymienionych w Commentarii. Jeżeli fragment uszkodzonej inskrypcji faktycznie zawierał numer nadany po jakimś czasie legionowi, to byłoby to równoznaczne z przyznaniem służącym w nim żołnierzom obywatelstwa rzymskiego. To zaś przesądzałoby ostatecznie o statusie Lorariusa. Problem w tym, że nie mamy żadnej pewności, czy 
gi na rozmiary wolnej przestrzeni, nie mógł zawierać nazwy tribus, do której centurion został przyporządkowany ${ }^{22}$, co na pierwszy rzut oka budzi poważne wątpliwości co do posiadania przez niego obywatelstwa rzymskiego. Lawrence Keppie zwrócił jednak uwagę, że nie wszystkie inskrypcje $\mathrm{z}$ okresu augustowskiego zawierają tego typu informacje ${ }^{23}$. Na serdecznym palcu lewej dłoni Lorariusa, która opiera się na głowicy miecza, można natomiast dostrzec pierścień (ryc. 2) będący oznaką przynależności do stanu ekwickiego (ordo equester). Ta zaś była możliwa wyłącznie w przypadku posiadania obywatelstwa rzymskiego. Po zakończeniu służby wojskowej Lorarius musiał je więc otrzymać, a zgromadzony majątek pozwolił mu na wejście do kategorii ekwitów. Siłą rzeczy musiał również być członkiem lokalnej elity. O takich przypadkach w odniesieniu do późnorepublikańskich centurionów pisał Horacy (Quintus Horatius

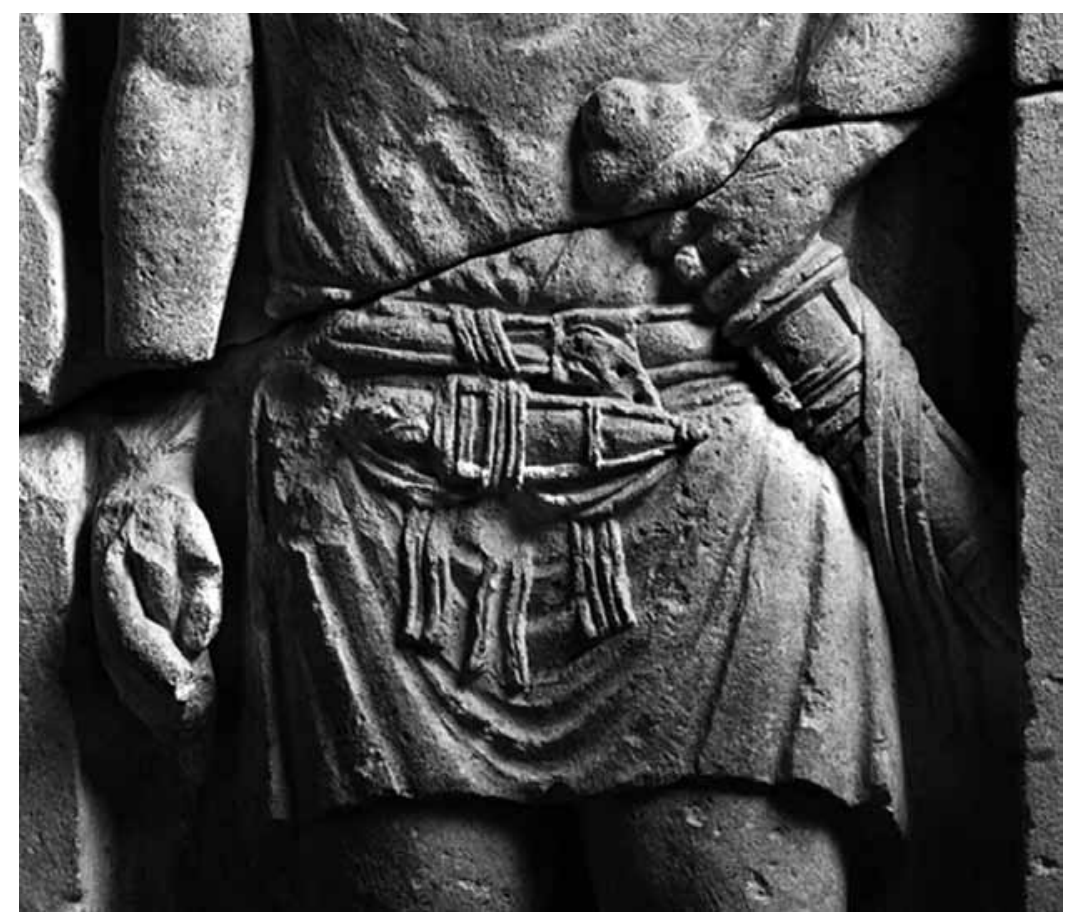

Ryc. 2. Detal płaskorzeźby centuriona Minuciusa Lorariusa (ze zbiorów Museo Archeologico, Padwa; źródło: Europeana free commons)

faktycznie był to numer legionu, szczególnie że zostałby zapisany po jego przydomku, co w świetle obecnej wiedzy byłoby praktyką bez precedensu, choć nie można jej całkowicie wykluczyć.

${ }^{22}$ Zob. przyp. 16.

${ }^{23}$ L. Keppie, A centurion of ..., s. 115. 
Flaccus) ${ }^{24}$. Ekwicki pierścień zdaje się zatem rozstrzygać kwestię obywatelstwa Lorariusa.

D'Amato przedstawił interpretację, jakoby przedmiot trzymany przez Lorariusa $\mathrm{w}$ prawej dłoni nie był rózga, lecz skórzanym pasem (względnie pasami ${ }^{25}$. Miałoby to korespondować $\mathrm{z}$ jego cognomen, będącym $\mathrm{w}$ istocie nadanym mu przez żołnierzy przezwiskiem (lorum oznacza "rzemień, „bat" ${ }^{26}$ ), analogicznie do Baculus ${ }^{27}$ czy caedo alteram ${ }^{28}$. O identyfikacji przedmiotu miałby przesądzać jego kształt, gdyż rzekoma rózga jest zbyt mocno skręcona, aby mogła być wykonana $z$ drewna.

Nie sposób zgodzić się z takim punktem widzenia. Po pierwsze: pędy winorośli potrafią być mocno skręcone, $\mathrm{z}$ czego $\mathrm{D}^{\prime}$ Amato jako Włoch powinien sobie zdawać sprawę, a nie można również

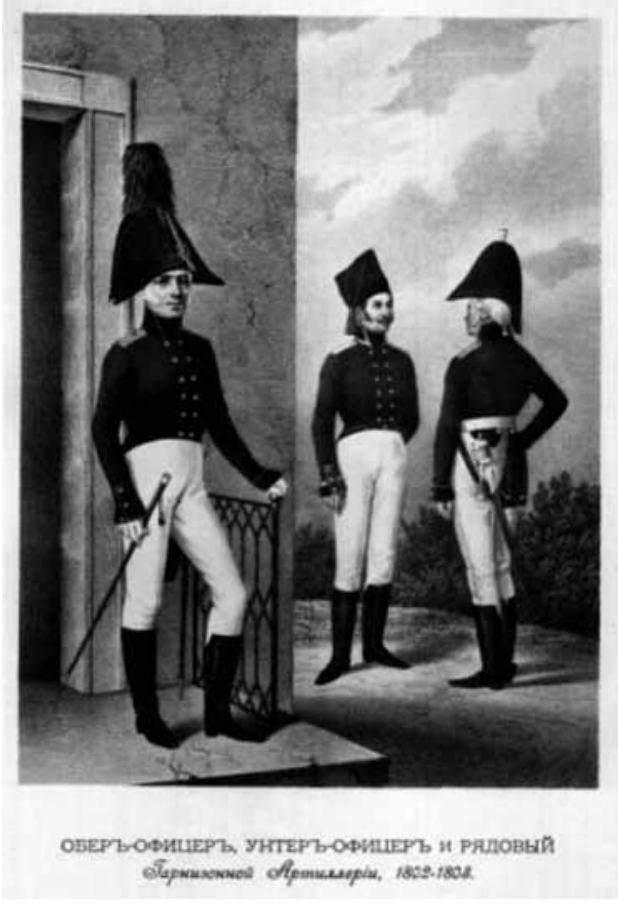

Ryc. 3. Rosyjska rycina przedstawiająca oficera z lat 1802-1803 trzymającego trzcinkę w sposób podobny do Lorariusa (źródło: www.1812db.simvolika.org) wykluczyć opcji niezbyt starannego przedstawienia vitis przez rzeźbiarza ${ }^{29}$, o czym będzie jeszcze mowa $\mathrm{w}$ przypadku kolejnego wyobrażenia centuriona. Po drugie: pomimo tego, że końcówka została stłuczona, to przedmiot ów wyraźnie sięgał do ziemi, co byłoby logiczne w przypadku rózgi (choćby na drodze analogii do przedstawień datowanych na okres cesarstwa), zaś niekoniecznie w przypadku pasa skóry. Po trzecie: sposób ułożenia dłoni przez Lora-

${ }^{24}$ Hor., Sat., 1.6.72-75.

${ }^{25}$ R. D'Amato, Roman Centurions 753-31 BC..., s. 33.

${ }^{26}$ Oxford Latin Dictionary (OLD), Oxford 1968, s. 1044.

${ }^{27}$ S. Hornblower, Stick, stones, and Spartans: the sociology of Spartan violence, [w:] War and Violence in Ancient Greece, red. H. van Wees, London-Swansea 2000, s. 61. Łaciński termin baculum jest równoznaczny z greckim baktēría i oznacza rózgę (OLD, s. 223).

${ }^{28}$ Tac., Ann., 1.23.2-3.

${ }^{29}$ O umiarkowanych zdolnościach rzemieślnika, który wykonał płaskorzeźbę nagrobna, może świadczyć m.in. zaburzenie proporcji ciała Lorariusa w postaci zbyt małej głowy w stosunku do tułowia, na co słusznie zwrócił uwagę L. Keppie, A centurion of..., s. 115. 
riusa jest typowy dla sztywnego przedmiotu, co potwierdza m.in. jeden $\mathrm{z}$ regulaminowych sposobów trzymania tzw. trzcinki przez oficerów XVIII- i XIX-wiecznych armii europejskich, a obecnie sił zbrojnych państw wchodzących w skład Commonwealthu oraz armii amerykańskiej (ryc. 3, 4). Można go także zobaczyć na pochodzących z I w. po Chr. płaskorzeźbach nagrobnych Marcusa Caeliusa (ryc. 5) i Marcusa Favoniusa Facilisa. Po czwarte: jeśli dokładnie przyjrzeć się dłoni Lorariusa, to górna część przedmiotu znajdująca się powyżej jej krawędzi ma przekrój owalny (ryc. 2), niezwykle trudny do osiągnięcia w przypadku pasa skóry, natomiast typowy dla drewnianej rózgi. Po piąte: fakt, że każdy przedstawiciel rodu Minucii Rufi nosił cognomen Rufus, nie sprawiał automatycznie, iż miał on rude włosy, tak samo jak gentilicum Porcius nie świadczyło, że każdy jego posiadacz zajmował się hodowlą trzody chlewnej. Etymologicznie cognomen Lorarius może najwyżej sugerować, że rodzina centuriona zajmowała się niegdyś wytwarzaniem skórzanych przedmiotów ${ }^{30}$. Po szóste wreszcie:

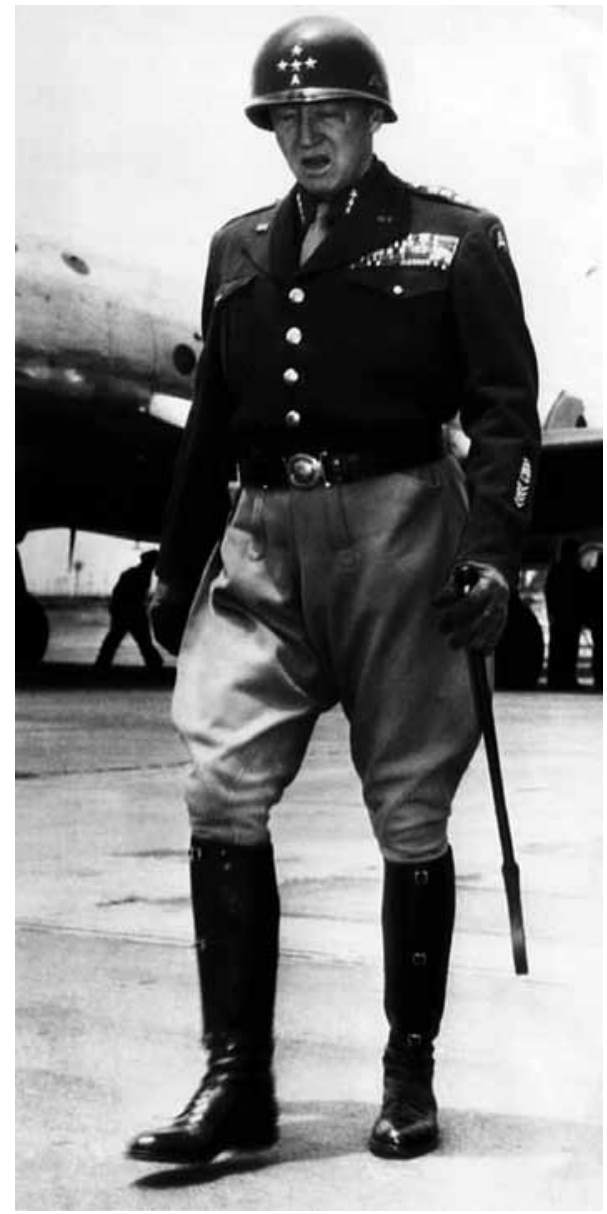

Ryc. 4. Fotografia przedstawiająca amerykańskiego gen. George'a S. Pattona trzymającego trzcinkę (szpicrutę?) w sposób podobny do Lorariusa (źródło: Wikipedia free commons) u schyłku republiki centurionowie otrzymali uprawnienia do wykonywania wobec żołnierzy kar cielesnych przy pomocy rózgi, co wynikało z chęci obejścia norm zawartych w leges Porciae $^{31}$. Byłoby dziwne, gdyby Lorarius zamiast symbolu sprawowanej funkcji, dobrze znanego z wczesnocesarskich przedstawień, dzierżył pasy skóry. Wszystko to czyni interpretację D’ Amato niemożliwą do przyjęcia.

${ }^{30}$ Ibidem, s. 115-116. Zob. także: OLD, s. 1044.

${ }^{31}$ Zob. M. N. Faszcza, Vitis centurionis, czyli o okolicznościach nadania centurionom symbolu ich rangi, „Przegląd Historyczno-Wojskowy” 2015, t. 2, s. 7-17. 


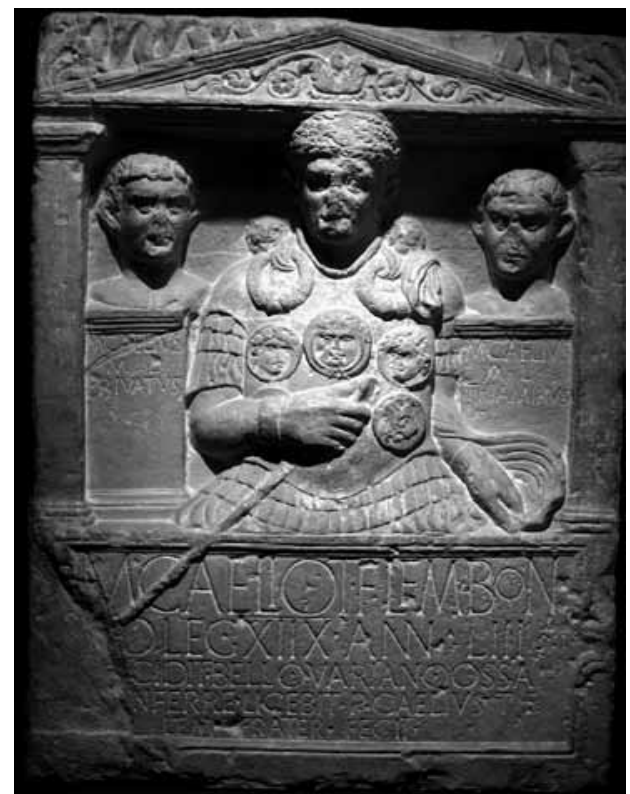

Ryc. 5. Płaskorzeźba nagrobna centuriona Marcusa Caeliusa (ze zbiorów Rheinisches Landesmuseum, Bonn; źródło: Wikipedia free commons)

Kontrowersje budzą także dwa otwory znajdujące się na wysokości uszu Lorariusa, po jednym z każdej strony. Istnieje domniemanie, że jest to ślad po niezachowanym wieńcu ${ }^{32}$. Jest to w pełni logiczne wytłumaczenie, ponieważ senat przyznał żołnierzom legio Martia prawo do noszenia wieńców oliwnych ${ }^{33} \mathrm{w}$ święta publiczne w dowód wdzięczności za porzucenie przez nich w 44 r. szeregów Antoniusza i wyjątkowo dzielną postawę okazaną podczas stoczonej w następnym roku bitwy pod Mutiną ${ }^{34}$.

Mimo to poważne wątpliwości wzbudzają dwie kwestie. Przede wszystkim należy pamiętać, że mamy do czynienia z płaskorzeźba, a zatem we wspomnianych otworach nie mogły być umieszczone haki podtrzymujące prawdziwy wieniec. Pomysł, że po każdej stronie znajdowały się jego części, jest zbyt absurdalny, aby traktować go poważnie. Zastosowanie wariantu z prawdziwym wieńcem wymagałoby również jego regularnej wymiany, a zatem byłoby to rozwiązanie kłopotliwe i rodzące ryzyko zaniedbania w przypadku wygaśnięcia lokalnej linii Minucii Lorari. Taki pomysł należy więc odrzucić.

Jeśli domniemanie dotyczące wieńca jest prawidłowe, to musiały być to fragmenty kamienne albo metalowe i tu kryje się kolejna słabość przedstawionej na wstępie hipotezy. Na głowie Lorariusa nie ma bowiem żadnych śladów, które świadczyłyby o przyleganiu do niej wieńca, a co więcej: pochodzące z I w. po Chr. przedstawienia wspomnianego już Caeliusa (ryc. 5) i innego centuriona, Quintusa Sertoriusa Festusa, świad-

${ }^{32}$ L. Keppie, A centurion of..., s. 116; R. D'Amato, Roman Centurions 753-31 BC..., s. 22,47

${ }^{33}$ Trudno ustalić, o jaki typ wieńca mogło chodzić, gdyż w rzymskich źródłach nie występują żadne wzmianki o wieńcach sporządzanych z liści oliwnych. Na temat coronae przyznawanych zwyczajowo w republikańskiej armii rzymskiej: V. A. Maxfield, The Military Decorations of the Roman Army, Berkeley-Los Angeles 1981, s. 67-81.

${ }^{34}$ App., BC, 3.74.303. 
czą o tym, że Rzymianie zwykli raczej wykuwać wieńce wojskowe (coronae) bezpośrednio na głowach postaci, a nie dodawać je $\mathrm{w}$ formie odrębnych detali. Oczywiście nie można wykluczyć prawdopodobieństwa, że w okresie augustowskim nie wykształcił się jeszcze powszechnie akceptowany usus w tym zakresie, lecz wystarczy spojrzeć na opisywaną płaskorzeźbę, aby dojść do wniosku, iż odległość otworów od krawędzi głowy jest zbyt duża, aby można w nich było zamocować wieniec bez naruszenia choćby elementarnego poczucia estetyki. Wieniec odstawałby wówczas od głowy na dobre kilka centymetrów, dotykając jej dopiero w okolicach czoła. Mamy zatem do czynienia z zagadka, której nie jesteśmy w stanie rozwiązać w sposób ostateczny.

Innym zagadnieniem jest długość służby wojskowej pełnionej przez Lorariusa. Jeżeli przyjąć, że okres istnienia legio Martia zamykał się w latach $49-42^{35}$, to wynika $\mathrm{z}$ tego, że Lorarius posiadał status żołnierza przez 7-8 lat. Odpowiada to $\mathrm{w}$ przybliżeniu przeciętnemu okresowi służby w legionach, który w okresie późnej republiki wynosił 6 lat ${ }^{36}$. Jeżeli jednak rację ma Keppie, kiedy twierdzi, że o legio Martia słyszymy po raz pierwszy podczas kampanii afrykańskiej $(47-46)^{37}$, to może się okazać, iż jednostka ta powstała dopiero w 47 r., co oznacza, iż Lorarius był żołnierzem dokładnie przez 6 lat. Korespondowałoby to z treścią datowanej na $44 \mathrm{r}$. Tabula Heracleensis, w której jest właśnie mowa o 6 latach służby dla żołnierzy piechoty ${ }^{38}$. Jest przy tym mało prawdopodobne, aby Lorarius poległ przed objęciem go demobilizacją, albowiem trudno sobie wyobrazić, w jakim trybie miałby wówczas zostać zaliczony w poczet ekwitów. Z kwestią długości jego służby wojskowej wiąże się zbyt wiele znaków zapytania, aby można ją było rozstrzygnąć w sposób niepozostawiający wątpliwości.

Pomimo zasygnalizowanych powyżej problemów interpretacyjnych nagrobek Lorariusa jest niezwykle cennym źródłem, które w istotny sposób uzupełnia informacje zawarte w przekazach literackich.

Jest to najwcześniejsze zachowane przedstawienie centuriona i nie jest przypadkiem, że pochodzi właśnie z tego okresu. W latach 49-30 doszło

${ }^{35}$ Zob. L. Keppie, The Making of..., s. 201; idem, The centurion of..., s. 115. H. M. D. Parker (The Roman Legions, New York 1958, s. 265) błędnie uznał, że legio Martia została całkowicie rozbita w 43 r. pod Mutiną.

${ }^{36}$ R.E. Smith, Service in the Post-Marian Roman Army, Manchester 1958, s. 6-7; P.A. Brunt, Italian Manpower 225 B.C.-A.D. 14, Oxford 1971, s. 400-401; W.V. Harris, War and Imperialism in Republican Rome 327-70 B.C., Oxford 1979, s. 44-45; L. Keppie, The Making of..., s. 33, 54, 62, 76; J. Patterson, Military organization and social change in the later Roman Republic, [w:] War and Society in the Roman World, red. J. Rich, G. Shipley, London-New York 1993, s. 98.

${ }^{37}$ L. Keppie, The centurion of..., s. 116, 118-119.

${ }^{38}$ Tab. Her., 2.89-91. 
do intensyfikacji procesu profesjonalizacji rzymskich sił zbrojnych, który sukcesywnie postępował począwszy od II wojny punickiej (218-201) ${ }^{39}$, ale - wbrew powszechnemu mniemaniu - aż do upadku republiki nie zakończył się wprowadzeniem armii zawodowej ${ }^{40}$. Długoletnie konflikty wewnętrzne musiały przyczynić się do powstania kategorii osób, które - podobnie jak na wpół legendarny Spurius Ligustinus ${ }^{41}$ - najlepsze lata spędziły w legionach, mając później problemy z odnalezieniem się w życiu cywilnym. To, że potrafimy zidentyfikować Lorariusa jako centuriona, wynika z okoliczności, że został on przedstawiony jako żołnierz, a zatem służba wojskowa stanowiła dla niego najważniejszy element samoidentyfikacji. Jest to najważniejsze novum, jakie przyniosły wojny domowe toczone w I w., albowiem, jak umiejętnie wykazali Claude Nicolet i William V. Harris, służba wojskowa stanowiła wcześniej jedną $\mathrm{z}$ wielu form aktywności publicznej, wynikającej z funkcjonowania rzymskich obywateli $\mathrm{w}$ ramach struktur państwa będącego polis, ze wszystkimi tego konsekwencjami $^{42}$. Można założyć, że Lorarius nie był pierwszym Rzymianinem, który uważał się w pierwszym rzędzie za żołnierza, ale okoliczność, że tego typu nagrobki zaczęły pojawiać się właśnie u schyłku republiki, mówi bardzo wiele o przemianach mentalności zachodzących w rzymskim społeczeństwie i nowej roli, jaką zaczęła odgrywać służba wojskowa. Można przypuszczać, że właśnie to stało się punktem wyjścia do ustanowienia przez Augusta armii zawodowej, nie zaś odwrotnie ${ }^{43}$.

Pierścień widniejący na palcu Lorariusa potwierdza także, że po zakończeniu służby wojskowej centurionowie posiadali na tyle wysoki status materialny, aby móc przejść do stanu ekwickiego. W przypadku Lorariusa był to podwójny awans społeczny, albowiem wszystko wskazuje na to, że wcześniej nie posiadał nawet obywatelstwa rzymskiego.

${ }^{39}$ W szczególności kwestię tę zaakcentowali: H. Delbrück, Geschichte der Kriegskunst im Rahmen der politischen Geschichte, Bd. I. Das Altertum, Berlin 1920, s. 500501; A. J. Toynbee, Hannibal's Legacy: The Hannibalic War Effects on Roman Life, Vol. II. Rome and Her Neighbours After Hannibal's Exit, Oxford 1965, s. 45-100, 128-135; E. Gabba, Republican Rome, the Army \& the Allies, przeł. P.J. Cuff, Oxford 1976, s. 5-13; L. Keppie, The Making of..., s. 51-55; G. Webster, The Roman Imperial Army of the First and Second Centuries A.D., Norman 1998, s. 15-16.

${ }^{40}$ J. Harmand, op. cit., s. 15-18; P. A. Brunt, op. cit., s. 430-514; J. W. Rich, The Supposed Manpower Shortage of the Later Second Century B.C., „Historia” 1983, t. 32, nr 3, s. 287-331.

${ }^{41}$ Liv. 42.34.1-12.

${ }^{42}$ C. Nicolet, The World of the Citizen in Republican Rome, przeł. P.S. Falla, BerkeleyLos Angeles 1976; idem, Obywatel, polityk, [w:] Człowiek Rzymu, red. A. Giardina, przeł. P. Bravo, Warszawa 1997, s. 27-67; W.V. Harris, op. cit., s. 41-53.

${ }^{43} \mathrm{Na}$ temat reform militarnych przeprowadzonych za panowania Augusta: Res gest., 17; Suet., Div. Aug., 49.1-3; Herod. 2.11; Cass. Dio 40.23-25. 


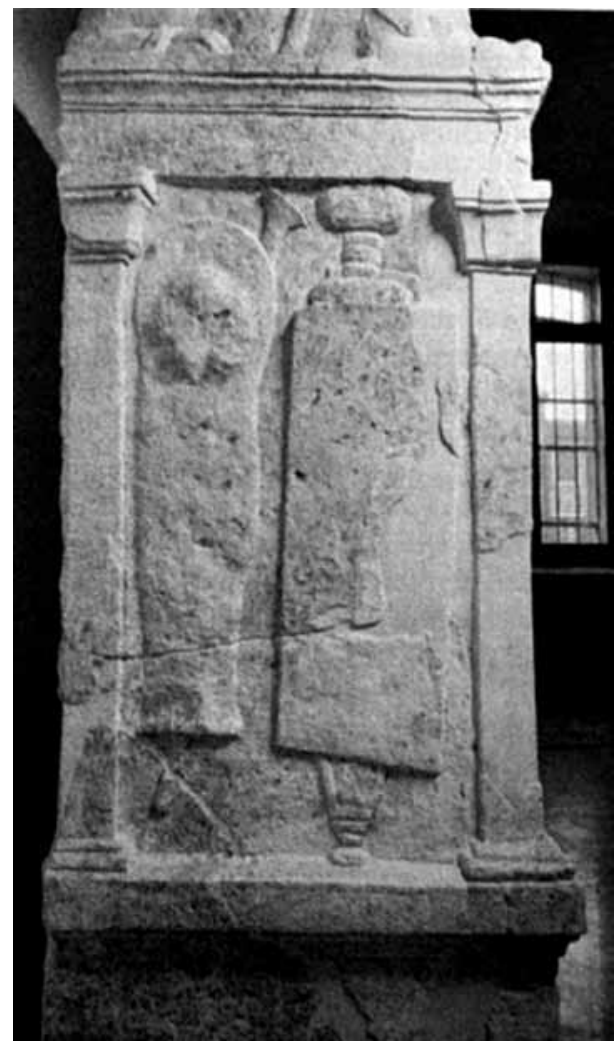

Ryc. 6. Płaskorzeźba nagrobna centuriona Luciusa Blattiusa Vetusa (ze zbiorów Museo Nazionale, Atestino; źródło: J. Osgood, Caesar's Legacy. Civil War and the Emergence of the Roman Empire, Cambridge 2008, s. 393)

W przekazach źródłowych można odnaleźć wzmianki nie tylko o byłych centurionach-ekwitach, ale również o przedstawicielach stanu ekwickiego, którzy wstępowali do armii, obejmując od razu stanowiska centurionów ${ }^{44}$. Nicolet zwrócił uwagę, że większość późnorepublikańskich ekwitów wywodziła się $\mathrm{z}$ rodów italskich niebiorących czynnego udziału w życiu politycznym Rzymu i niewykazujących przywiązania do tradycyjnego wizerunku swojej grupy społecznej ${ }^{45}$. Wzrost znaczenia centurionów, objawiający się m.in. wzrostem przyznawanych im poborów oraz rozszerzeniem zakresu kompetencji ${ }^{46}$, przyczynił się zatem do powstania przeświadczenia o możliwości uzyskania szybkiego awansu społecznego dzięki służbie w armii w stopniu centuriona. Lorarius jest tego dobrym przykładem, choć znane są nawet przypadki, kiedy dzięki protekcji swoich wodzów zdemobilizowani centurionowie stawali się senatorami ${ }^{47}$.

Inna zachowana płaskorzeźba nagrobna została wykonana dla uczczenia Luciusa Blattiusa Vetusa (ryc. 6). Datuje się ją na koniec I w. albo na pierwszą połowę I w. po Chr. ${ }^{48}$ Istnieją poważne przesłanki, aby przypuszczać, że ów centurion rozpo-

${ }^{44}$ Caes., BC, 2.18.4; BHisp., 25.4-7; Cic., Phil., 1.20; CIL X 3903.

${ }^{45}$ C. Nicolet, L'ordre équestre à l'époque républicaine (312-43 av. J.-C.), Vol. I, Paris 1966, s. $387-415,457-464$.

${ }^{46}$ Zob. M. N. Faszcza, Wzrost dyscyplinarnych uprawnień centurionów w I w. p.n.e., [w:] Armia i systemy obronne w Imperium Rzymskim, red. H. Kowalski, P. Madejski, Lublin 2015, s. 11-25.

${ }^{47}$ Cic., ad Att., 14.10.2; Sall., Cat., 37.6; Cass. Dio 48.22.3; Oros. 5.21.3.

${ }^{48}$ L. Keppie, Colonisation and Veteran Settlement in Italy, 47-14 BC, Rome 1983, s. 214; J. Osgood, op. cit., s. 391; R. D'Amato, Roman Centurions 31 BC-AD 500..., s. 6, 44. 
czął swoją karierę najpóźniej w latach trzydziestych I w. Pierwszą z nich jest przynależność Vetusa do legio IIII (IV) Macedonica, o czym świadczy fragment mocno uszkodzonej inskrypcji:

$$
\begin{gathered}
\mathrm{L} \text { (vcivs) Bla[t]tivs L(vcii) f(ilivs) Ro[m(vlia) tribv] / Vetvs } \\
\text { cent(vrio) leg(ionis) I[III] M[ace]don(icae) adle[ct(vs) de]curio }{ }^{49}
\end{gathered}
$$

Był to legion, który w 30 r. otrzymał od Cezara Młodszego ziemię w Ateste (współ. Este) ${ }^{50}$. Opisywana płaskorzeźba została zaś odnaleziona właśnie w jego okolicach, a ściślej mówiąc we Fregose, gdzie Vetus po zwolnieniu z legionu pełnił funkcję dekuriona ${ }^{51}$. Jest to kolejne potwierdzenie wysokiego statusu materialnego ekscenturionów, podobnie jak w przypadku Lorariusa. Drugą przesłanką jest natomiast dekoracja górnej części rózgi. Pozostawała ona do tej pory niezauważona, głównie ze względu na jej bardzo niewyraźny zarys, trudny do uchwycenia na fotografiach. Zwrócenie na nią uwagi jest zasługą D'Amato. Ustalił on mianowicie, że lekkie nacięcia zostały sporządzone w taki sposób, aby całość przypominała kwiat lotosu. Być może górna część rózgi była pierwotnie pomalowana, co ułatwiałoby rozpoznanie dekoracji. Zdaniem włoskiego archeologa dowodzi to, że Vetus pełnił służbę na terenie Egiptu ${ }^{52}$, co jest o tyle prawdopodobne, że legio IIII najpewniej brała udział w kampanii akcyjskiej i wraz z Cezarem Młodszym znalazła się w 30 r. pod murami Aleksandrii ${ }^{53}$.

Rzecz jasna, nie przesądza to o stosowaniu przez Vetusa tego typu rózgi podczas wykonywania obowiązków centuriona. Była to raczej forma podkreślenia faktu, że przez pewien czas przebywał w Egipcie i był świadkiem ostatecznego triumfu Cezara Młodszego. Możliwe, że pokazywał się z nią tylko w sytuacjach oficjalnych: $\mathrm{z}$ jednej strony jej ewidentnie ozdobny charakter nie mógł robić większego wrażenia na podwładnych, którzy przebyli wraz z nim ten sam szlak bojowy, zaś z drugiej wykorzystywanie jej do chłostania żołnierzy narażałoby ją na poważne ryzyko uszkodzenia, które - jak potwierdza przydomek cedo alteram ${ }^{54}$ - co jakiś

${ }^{49}$ AE 1893, 119 .

${ }^{50}$ ILS 2340; L. Keppie, Colonisation and Veteran..., s. 22, 24-25.

${ }^{51}$ Zob. przyp. 49.

${ }^{52}$ R. D'Amato, Roman Centurions 31 BC-AD 500..., s. 6, 44.

${ }^{53}$ L. Keppie, The Making of..., s. 206. Keppie wyraził wątpliwość, czy aby na pewno legio IIII Macedonica brała udział w kampanii akcyjskiej, niemniej wydaje się, że jego ostrożność była nadmierna, gdyż trudno byłoby w takiej sytuacji wytłumaczyć, dlaczego żołnierze służący w tej jednostce zostali objęci nadziałami ziemi w tym samym roku, co inni weterani kampanii lat 31-30.

${ }^{54}$ Zob. przyp. 28. 
czas się zdarzało. Nie można nawet wykluczyć, że nigdy w rzeczywistości nie istniała, ponieważ sposób jej przedstawienia sugeruje, iż rzeźbiarz nie widział na własne oczy rózgi centuriona. Rodzina zmarłego być może pragnęła podkreślić okoliczność pełnienia przez Vetusa służby w Egipcie, zlecając wykonanie takiej dekoracji. Nawiasem mówiąc, dziwny kształt rózgi koresponduje z przedstawieniem widniejącym na nagrobku Lorariusa, gdyż w obu przypadkach trudno na pierwszy rzut oka rozpoznać, z jakim przedmiotem mamy do czynienia. Występujący w XIX w. podział na zwykłe i ozdobne trzcinki oficerskie - wyraźnie widoczny na zachowanych fotografiach - pozwala jednak domniemywać, że ozdobiona kwiatem lotosu rózga Vetusa istniała naprawdę.

Uderzające jest, że jedyne zachowane płaskorzeźby nagrobne późnorepublikańskich centurionów dotyczą legionów o zbliżonej historii. Legio IIII Macedonica była bowiem jednostka, która w 44 r. zbuntowała się wraz z legio Martia przeciwko Antoniuszowi ${ }^{55}$, a rok później obie uczestniczyły w bitwach pod Forum Gallorum i Mutiną ${ }^{56}$. Lorarius i Vetus należeli zatem nie tylko do tego samego pokolenia, ale przez szereg lat pozostawali towarzyszami broni i z dużą dozą prawdopodobieństwa można założyć, że nie byli dla siebie anonimowi.

Płaskorzeźba poświęcona Vetusowi nie zawiera jego sylwetki, a jedynie wyposażenie, które zostało ukazane w sposób bardzo schematyczny i w zasadzie bezwartościowy, jeśli chodzi o zaawansowane studia bronioznawcze. Tarcza jest po prostu krzywym prostokątem przypominającym romb, za to zasłaniający rózgę nagolennik (ocrea) stanowi dowód na stosowanie tego typu ekwipunku przez pierwszowiecznych centurionów - ponownie nie jesteśmy w stanie rozstrzygnąć, czy dotyczyło to sytuacji oficjalnych, czy też zabezpieczano nimi golenie podczas bitew ${ }^{57}$.

Znacznie ciekawsze jest przedstawienie przyznanych Vetusowi odznaczeń, wyobrażonych na drugiej stronie monumentu. Są nimi phale$r^{r a e^{58}} \mathrm{w}$ liczbie dziewięciu oraz dwie bransolety (armillae) ${ }^{59}$. Wskazuje to na niepoślednie zasługi bojowe Vetusa, w związku z czym nie dziwi, że po jego śmierci rodzina (bądź on sam, zakładając, że nagrobek został wyko-

\footnotetext{
${ }^{55}$ Zob. przyp. 20.

${ }^{56}$ Na temat przebiegu obu bitew: Cic., ad fam., 10.30, 11.13.2; Suet., Div. Aug., 10.4; App., BC, 3.65-72; Cass. Dio 46.37-38.

${ }^{57}$ Zob. M.C. Bishop, J.C.N. Coulston, Roman Military Equipment from the Punic Wars to the Fall of Rome, Oxford 2009, s. 64-65; R. D'Amato, G. Sumner, Arms and Armour of the Imperial Roman Soldier. From Marius to Commodus, 112 BC-AD 192, London 2009, s. 43.

${ }^{58}$ Zob. V.A. Maxfield, op. cit., s. 91-95. Ukazany na nagrobku Vetusa sposób mocowania phalerae do skórzanych pasów sugeruje, że metoda typowa dla okresu cesarskiego (ibidem, s. 93, pl. 11, 94, pl. 12) była już rozpowszechniona u schyłku republiki.

${ }^{59}$ Zob. ibidem, s. 89-91.
} 
nany jeszcze za jego życia) postanowiła uwiecznić bohaterstwo krewniaka. Zakładając, że Vetus miał okazję przejść wraz z Cezarem Młodszym cały szlak bojowy, miał on szansę wykazać się w 43 r. pod Forum Gallorum/Mutina, w 42 r. pod Filippi oraz w 41 r. pod Peruzją ${ }^{60}$. Biorąc pod uwage poprawność identyfikacji dokonanej przez D’Amato (dotyczącej uczestnictwa w kampanii egipskiej), Vetus nie miał okazji uczestniczyć tam $\mathrm{w}$ walkach o poważniejszym charakterze, za to nie można wykluczyć, że został $w$ jakiś sposób odznaczony za raczej symboliczne zajęcie Aleksandrii w $30 \mathrm{r}$.

Zarówno płaskorzeźba Lorariusa, jak i Vetusa przekonują że symbolem, dzięki któremu rozpoznawano centurionów, była rózga. Przedstawienie vitis należącej do Vetusa sugeruje jednak, że niekoniecznie musiano sobie zdawać sprawę z jej dokładnego wyglądu, choć innym wytłumaczeniem jej specyficznego kształtu mogły być niskie umiejętności rzeźbiarza. W obu przypadkach nie uwieczniono natomiast hełmów z poprzecznym grzebieniem (crista transversa), z którymi także kojarzono centurionów ${ }^{61}$. Wyobrażenia zawarte na reliefach z Campidoglio i Akwilei sugeruja, że być może $w$ okresie republiki ten typ grzebienia był typowy dla wszystkich dowódców, nie tylko dla centurionów. Z kolei relief odnaleziony w Akwilei wskazuje na to, że innym rodzajem wyróżnika mogły być pojedyncze pióra zamocowane po obu stronach grzebienia/kity biegnącego/ej wzdłuż hełmu. Można się domyślać, że w warunkach trwającej kampanii stosowano różne oznaki, w zależności od dostępnych możliwości. Kluczowe znaczenie miało przede wszystkim wyróżnianie się na tle pozostałych żołnierzy, nie zaś wierność nieujętej w ramach żadnego regulaminu tradycji.

Z crista transversa w kontekście centurionatu mamy za to do czynienia w przypadku jednego z odnalezionych fragmentów nagrobku Publiusa Ventidiusa Bassusa (ryc. 7), datowanego na 35 r. ${ }^{62}$ Bassus należał do najzdolniejszych dowódców Antoniusza i wsławił się odparciem partyjskiego najazdu w 38 r., za co został uhonorowany triumfem ${ }^{63}$. Po prawej stronie steli ukazującej trzech zbrojnych widnieje postać stylizowana na żołnierza w hełmie udekorowanym poprzecznym grzebieniem. W prawej dłoni trzyma on podłużny przedmiot, który może być rózga, albo - co

\footnotetext{
${ }^{60}$ L. Keppie, The Making of..., s. 206.

${ }^{61}$ M. Durry, Note sur la tenue des centurions (la crista transversa), „Revue Archéologique” 1928, t. 27, 303-308; R. D'Amato, Roman Centurions 753-31 BC..., s. 34.

${ }^{62}$ T. Hölscher, Historische Reliefs, [w:] Kaiser Augustus und die verlorene Republik, red.

W. D. Heilmeyer, E. La Roca, E. Künzl, Mainz 1988, s. 363.

${ }^{63}$ T. R. S. Broughton, The Magistrates of the Roman Republic, Vol. II, New York 1952, s. 393.
} 


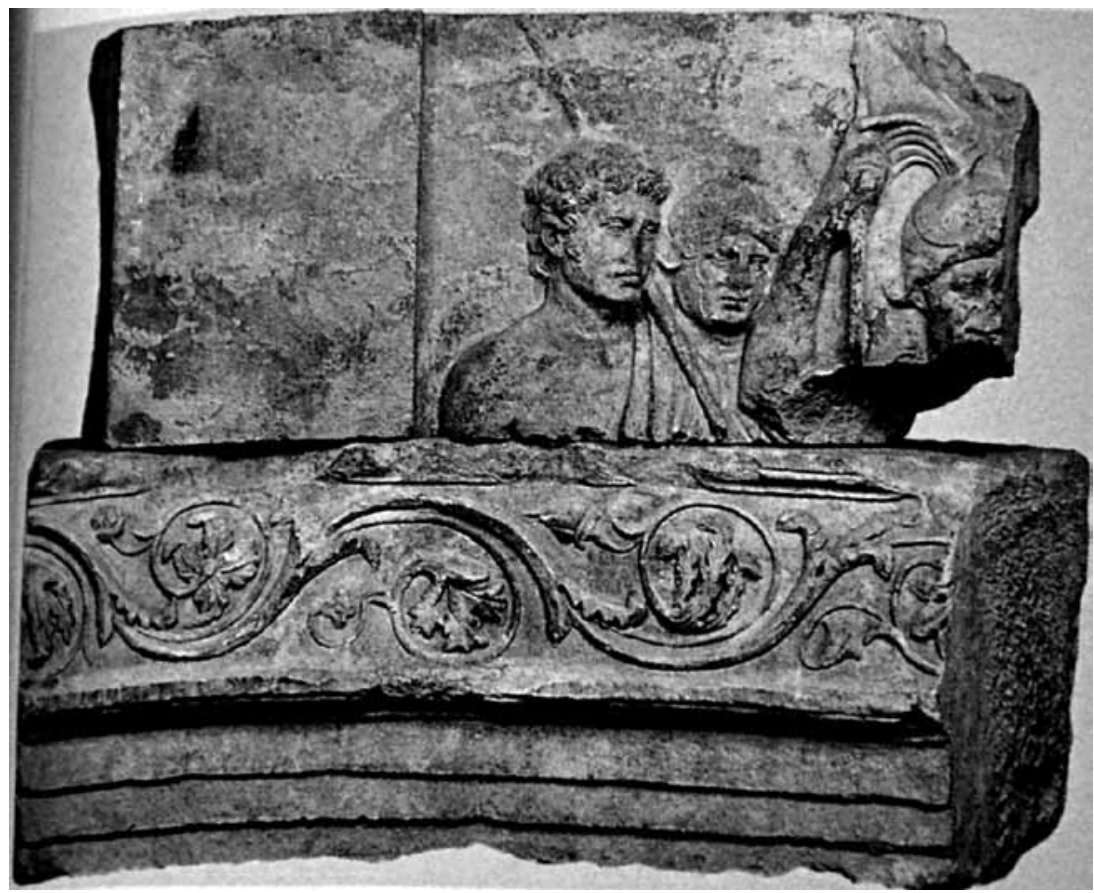

Ryc. 7. Fragment płaskorzeźby nagrobnej Publiusa Ventidiusa Bassusa (ze zbiorów Palazzo dei Conservatori, Rzym; źródło: T. Hölscher, Historische Reliefs, [w:] Kaiser Augustus und die verlorene Republik, red. W.-D. Heilmeyer, E. La Roca, E. Künzl, Mainz 1988, s. 365)

bardziej prawdopodobne - włócznia/oszczepem. Crista transversa sugeruje, że mamy do czynienia z dowódcą. Podłużny przedmiot, o ile nie jest rózga, nie stanowi żadnej wskazówki, ponieważ postać przedstawiona na tzw. ołtarzu Domitiusa Ahenobarbusa także dzierży włócznię, a ponad wszelką wątpliwość nie jest centurionem. Na płaskorzeźbie z 35 r. żołnierza nie tylko wyróżnia jednak crista transversa, ale także brak elementów ozdobnych, będących regularnym motywem występującym w przypadku oficerów $^{64}$. Nie ma przy tym znaczenia, czy chodziło stricte o centuriona, czy jest to po prostu postać ukazana przy wykorzystaniu atrybutów typowych dla centuriona - jej obecność na reliefie raczej nie jest przypadkowa, co każe zastanowić się nad powodem, dla którego ją wykorzystano.

${ }^{64}$ Z pewnością nie można za taki uznać „brwi” biegnących w poprzek przedniej części dzwonu, ponieważ był to element mający służyć zabezpieczeniu hełmu przed pęknięciem $\mathrm{w}$ wyniku silnego ciosu zadanego na wprost. Innowacja ta została prawdopodobnie wprowadzona w legionach pod wpływem celtyckich płatnerzy (J.-L. Brunaux, B. Lambot, Guerre et armement chez les Gaulois (450-52 av. J.-C.), Paris 1987, s. 106-107; A. Deyber, Les Gaulois en guerre. Stratégies, tactiques et techniques, Paris 2009, s. 289). 
Wykluczone, aby relief ten miał przedstawiać żołnierzy służących w konkretnym legionie czy podczas konkretnej kampanii - chodziło tutaj o podkreślenie okraszonej sukcesami kariery militarnej Bassusa. Korespondowały z nią dwie cnoty: Virtus i Honos, zidentyfikowane przez Tonio Hölschera jako dwie $\mathrm{z}$ trzech postaci przedstawionych na reliefie ${ }^{65}$. Co do trzeciej, znajdującej się na prawym skraju i noszącej hełm z crista transversa, niemiecki archeolog nie miał jasnego poglądu. Scharakteryzował ją po prostu jako dowódcę, być może nawet samego Bassusa $^{66}$.

Przeoczył jednak fakt, że zamiast typowego hellenistycznego hełmu, ukazywanego $\mathrm{w}$ takich przypadkach (czego przykład stanowi choćby obecna na tym samym reliefie Virtus), postać ta posiada ochronę głowy typu italo-attyckiego, względnie Buggenum albo Coolus, z daszkami policzkowymi, czyli w formie hełmu znajdującego się na wyposażeniu armii rzymskiej ${ }^{67}$. Nie wiadomo też, dlaczego personifikacja jednej z cnót miałaby nosić na hełmie crista transversa zamiast klasycznego grzebienia, jak wspomniana już Virtus bądź liczne znane przedstawienia Marsa czy Romy. O ile koncepcja Hölschera dotycząca Honos i Virtus nie budzi większych wątpliwości i potwierdzają ją choćby monety emitowane w okresie późnorepublikańskim ${ }^{68}$, o tyle wydaje się, że ostatni mężczyzna miał uosabiać po prostu rzymskiego żołnierza. Gdyby było inaczej, artysta nie poświęciłby tak dużo uwagi odwzorowaniu uzbrojenia stosowanego w jego czasach, a zamiast tego posłużyłby się konwencją zaczerpniętą ze sztuki hellenistycznej, obecnej w sztuce rzymskiej również w kolejnych wiekach ${ }^{69}$.

Pytaniem jest, czy stylizacja archetypicznego miles Romanus na centuriona była w tym przypadku w pełni świadoma, a jeśli tak, to jaki efekt

${ }^{65}$ T. Hölscher, op. cit., s. 363.

${ }^{66}$ Ibidem.

${ }^{67}$ M. C. Bishop, J. C. N. Coulston, op. cit., s. 65-66; R. D'Amato, G. Sumner, op. cit., s. 112, 239. Jednoznaczną identyfikację hełmu jako typ Buggenum przedstawił: H. Russel Robinson, The Armour of Imperial Rome, London 1975, s. 16. Kwestią sporna pozostaje, czy w I w. produkowano hełmy italo-korynckie, ponieważ nie odnaleziono żadnego egzemplarza pochodzącego z tego okresu, w przeciwieństwie do czasu panowania Augusta. $Z$ drugiej strony nie jest znany także pierwszowieczny hełm italo-koryncki, często przedstawiany na płaskorzeźbach rzymskich datowanych na V-I w. Por. mocno uproszczone stanowisko zaprezentowane ostatnio przez: H. Travis, J. Travis, Roman Helmets, Stroud 2014, s. 46.

${ }^{68}$ RRC I, s. 412, 413, 482; RRC II, tab. L/4, 7, LVII/22. Zob. także: M. McDonnell, Roman Manliness. Virtus and the Roman Republic, Cambridge 2006, s. 42, 212, 230, 234-235, 266.

${ }_{69}$ Zob. T. Hölscher, Sztuka rzymska: jezyk obrazowy jako system semantyczny, przeł. L. Olszewski, Poznań 2011, s. 52-73. 
pragnął osiągnąć fundator. Warto zwrócić uwagę, że ów centurion (czy może raczej „centurion”) znajduje się w otoczeniu Virtus i Honos - cnót tradycyjnie utożsamianych z obywatelem-żołnierzem, a co więcej: ściśle korespondujących $\mathrm{z}$ mechanizmami przyznawania awansu na stanowisko centuriona, gdyż w okresie schyłku republiki premiowano przede wszystkim brawurę okazywaną na polu walki ${ }^{70}$. Idealnym przykładem tego zjawiska jest Publius Crastinus, który prowadząc w 48 r. pod Farsalos pierwszy atak na linie pompejańczyków poczytywał sobie taką postawę za honor (honos), a której nie byłby w stanie zrealizować, gdyby nie odwaga oraz odpowiedni stosunek do wodza i ojczyzny (virtus ${ }^{71}$. Możemy mieć zatem do czynienia z manifestacją przeświadczenia, że postacią która w najpełniejszym stopniu wyraża obie te cechy, jest właśnie centurion.

$\mathrm{Z}$ takim domniemaniem korespondują inne przesłanki. Awans na stopień centuriona był maksymalnym osiągnięciem dostępnym zwykłemu żołnierzowi pochodzącemu z poboru. Stanowiska oficerskie były bowiem zarezerwowane dla przedstawicieli centurii ekwickich i nie były obsadzane na drodze dilectus ${ }^{72}$. Zważywszy na zasadę przyznawania awansów, każdy dorosły obywatel rzymski zdawał sobie sprawę, że teoretycznie to centurionowie byli "najdzielniejszymi z dzielnych". O poważaniu, jakim cieszyli się w społeczeństwie, oraz ich wysokiej pozycji społeczno-majątkowej świadczy okoliczność, że w okresie republiki to wyłącznie centurionowie zwykli manifestować posiadaną rangę na nagrobkach. Zastanawiające jest również, że wszystkie późnorepublikańskie inskrypcje wojskowe o charakterze prywatnym wspominają wyłącznie o centurionach ${ }^{73}$. Ich elitarny status jest zatem niekwestionowany. Co więcej, liczba chwalebnych

${ }^{70}$ H. Delbrück, op. cit., s. 515-516; R. E. Smith, op. cit., s. 66-67; J. Harmand, op. cit., s. 328, 336-344; A.K. Goldsworthy, The Roman Army at War 100 BC-AD 200, Oxford 1996, s. 123-124, 132; J. E. Lendon, Soldiers \& Ghosts. A History of Battle in Classical Antiquity, New Haven-London 2005, s. 218-219; R. D'Amato, Roman Centurions 753-31 BC..., s. 11.

${ }^{71}$ Caes., BC, 3.91.1-3, 3.99.3-4; Plut., Pomp., 71.3; App., BC, 2.82.347-348. Por. Luc., Phar., 7.471-472; Flor. 2.13.46. Znana jest również forma jego nazwiska "Crassinius", ale decydujący w tej kwestii jest przekaz Cezara, w którego armii służył przecież Crastinus, i który nakazał wznieść mu po bitwie monument nagrobny upamiętniający jego bohaterstwo.

72 Zob. J. Harmand, op. cit., s. 324, 327, 349-383. Wyjątek być może stanowiło stanowisko prefekta obozu (praefectus castrorum), w okresie cesarstwa powierzane wysłużonym centurionom (L. Keppie, The Making of..., s. 179; G. Webster, op. cit., s. 114; Y. Le Bohec, The Imperial Roman Army, przeł. R. Bate, London-New York 2001, s. 39), ale dla I w. wspomina o nim wyłącznie jedno źródło, i to w sposób pozbawiony szerszego kontekstu (BHisp., 32.7).

${ }^{73}$ Zob. L. Keppie, Military service in the Late Republic: the evidence of inscriptions and sculpture, "Journal of Roman Military Equipment Studies” 1997, t. 8, s. 3-11. 
epizodów z udziałem centurionów, zawartych w dziełach Cezara (Caius Iulius Caesar) i Liwiusza (Titus Livius), jest tak znaczna, że nie może być wątpliwości nie tylko dotyczących faktycznego znaczenia centurionów podczas bitew, ale również upatrywania w nich w I w. chluby armii rzymskiej. Jeśli zatem Virtus i Honos miały stanowić otoczenie rzymskiego żołnierza, to zbrojnym, który w powszechnym odczuciu najlepiej uosabiał obie te cechy, był właśnie centurion.

Zastanawiające jest, czy takie skojarzenia były czytelne dla ogółu społeczeństwa i do kogo były przede wszystkim adresowane. John R. Clark przekonująco wykazał bowiem, że sztuka rzymska rzadko była kierowana do wszystkich obywateli, a fundatorzy koncentrowali się zazwyczaj na własnej grupie społecznej ${ }^{74}$. W przypadku Bassusa nie ma wątpliwości, że chodziło głównie o nobilitas, którym pragnął się przedstawić w glorii vir militaris. Mimo to wydaje się, że połączenie Virtus, Honos i żołnierza stylizowanego na centuriona było czytelne dla większości obywateli rzymskich. Wszyscy dorośli mężczyźni podlegali bowiem powszechnemu obowiązkowi służby wojskowej ${ }^{75}$, a większość z nich faktycznie musiała $\mathrm{w}$ toku długotrwałych wojen domowych odbyć kilkuletnią służbę $\mathrm{w}$ legionach ${ }^{76}$. Doskonale zdawali sobie zatem sprawę, kim są centurionowie i jakie cechy są w ich przypadku premiowane. Mieli okazję widzieć, że ich kadry tworzono spośród najdzielniejszych żołnierzy, wymagając od nich podczas bitew dawania przykładu podwładnym ${ }^{77}$. Gdyby pełnienie stanowiska centuriona nie było odbierane w społeczeństwie jako powód do dumy, to nie manifestowano by tego na nagrobkach i w treści inskrypcji. Nawet jeśli większość obywateli rzymskich nie znała treści dzieł Cezara i Liwiusza, to doskonale rozumiała przyczyny, dla których tak silnie eksponowano $\mathrm{w}$ nich dokonania centurionów. Wszystko to sprawia, że zachowany fragment nagrobku Bassusa mógł po prostu stanowić kolejną formę wyrazu tendencji rozpowszechnionej już w jego czasach. Skoro najdzielniejsi żołnierze zostawali centurionami, to właśnie oni nadawali się na najlepszych wyrazicieli honos i virtus.

${ }^{74}$ J.R. Clarke, Art in the lives of ordinary Romans. Visual representation and non-elite viewers in Italy, 100 B.C.-A.D. 315, Berkeley-Los Angeles 2003.

${ }^{75}$ Zob. przyp. 40.

${ }^{76}$ Zob. analiza liczby mężczyzn powołanych pod broń w okresie wojen domowych toczonych w latach 44-30: P. A. Brunt, op. cit., s. 473-512.

77 Było to zresztą powodem bardzo wysokich strat wśród centurionów, przewyższających pod względem stosunku zabitych do ogólnej liczby wszystkie pozostałe kategorie żołnierzy (J. Harmand, op. cit., s. 341-342; A. K. Goldsworthy, The Roman Army..., s. 182; P. Sabin, The Face of Roman Battle, "The Journal of Roman Studies" 2000, t. 90, s. 11; J.E. Lendon, op. cit., s. 302). 


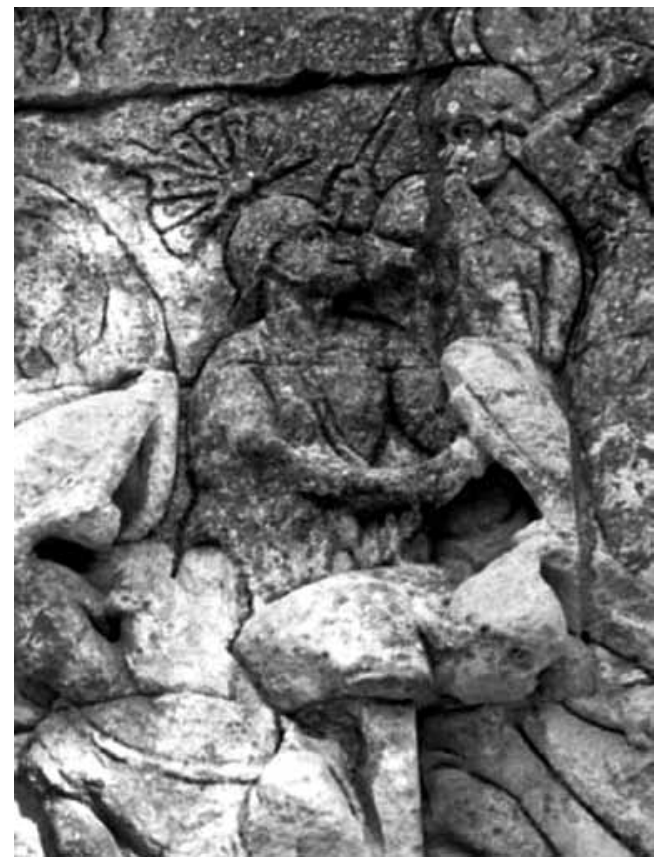

Ryc. 8. Fragment łuku z Glanum (St. Remy; źródło: R. D’Amato, Roman Centurions 753-31 BC. The Kingdom and the Age of Consuls, Oxford 2011, s. 18)

Niewykluczone, że z centurionem mamy także do czynienia w przypadku łuku komemoratywnego z Glanum (współ. St. Remy; ryc. 8). Perspektywa przedstawiona na płaskorzeźbie jest jednak zbyt silnie zaburzona, aby można było mieć pewność, czy pióropusz widniejący na hełmie został umocowany wzdłuż, czy w poprzek dzwonu. Mimo to wydaje się, że jego posiadaczem jest centurion, a to na podstawie wyraźnie widocznego pendentu biegnącego od prawego ramienia do lewego boku. Wiadomo, że w taki sposób miecze nosili właśnie centurionowie $^{78}$ albo - wnioskując na podstawie opisywanego monumentu - żołnierze służący w konnicy. Domniemany centurion jest jednak piechurem i upatrywanie w nim spieszonego jeźdźca, który być może przed chwilą stracił wierzchowca, byłoby chyba zbyt karkołomne. Dodatkowym argumentem na rzecz zaliczenia tej zagadkowej postaci do kategorii centurionów jest jej pióropusz, odmienny od kit zdobiących hełmy pozostałych żołnierzy ukazanych na łuku. Jest to więc z pewnością dowódca: centurion albo oficer. Wszystko zależy od tego, czy uzna się, że na hełmie widnieje crista transversa, czy też nie. W moim odczuciu, pomimo zachwianej perspektywy, odmienny kąt ułożenia pióropusza w stosunku do profilu postaci przemawia za uznaniem jej za centuriona.

Łuk z Glanum został wzniesiony za panowania Augusta, prawdopodobnie jeszcze w I w., ale upamiętnia podbój Galii dokonany przez jego przybranego ojca - Cezara ${ }^{79}$. Trudno w związku z tym dokładnie rozstrzygnąć, do jakiego etapu rozwoju rzymskiej wojskowości nawiązuje wygląd centuriona. Czas powstania monumentu oraz niewystępowanie w okre-

${ }^{78}$ Zob. przyp. 14.

${ }^{79}$ G. Ch. Picard, Les Trophées romains. Contribution à l'histoire de la religion et de l'art triomphal de Rome, Paris 1957, s. 319-325; H. Rolland, L'Arc de Glanum, XXXI'e supplément à "Gallia”, Paris 1977. 


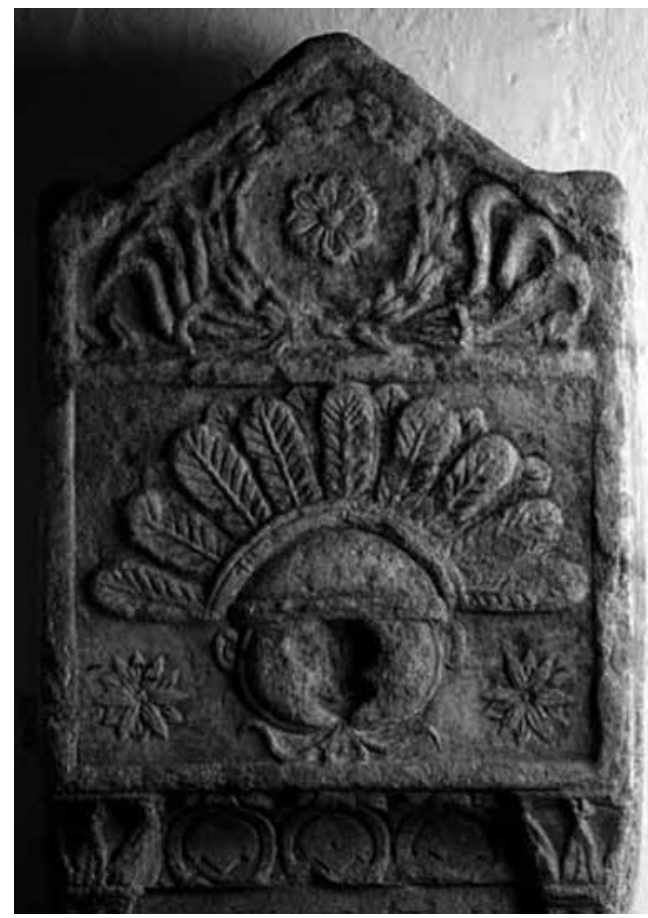

Ryc. 9. Płaskorzeźba nagrobna centuriona Marcusa Petroniusa Classicusa Murrucinusa (ze zbiorów Pokrajinski Muzej, Ptuj; źródło: Europeana free commons) sie republiki oddziałów jazdy sprzymierzeńczej wyekwipowanej na sposób rzymski ${ }^{80}$ wskazują raczej na późniejszy okres niż lata 58-51. Wszystko to jednak przy założeniu, że przedstawiona konnica nie miała składać się W zamyśle fundatorów $\mathrm{z}$ obywateli rzymskich, co nie jest wcale takie pewne, ponieważ w I w. rodzima jazda była co jakiś czas formowana na potrzeby konkretnych kampanii ${ }^{81}$. Bardzo ogólnie można więc określić wygląd centuriona na lata 58-10, co nie czyni większej różnicy, albowiem zarówno typ noszonego przez niego hełmu (Coolus), jak i pancerz torsowy były stosowane $\mathrm{w}$ armii wczesnocesarskiej ${ }^{82}$.

Poza potwierdzeniem noszenia przez centurionów crista transversa i mieczy przy lewym boku trudno wyciągać na podstawie płaskorzeźby z Glanum jakiekolwiek szersze wnioski. Ciekawostką jest natomiast pióropusz, a nie grzebień/kita - zwyczaj jego noszenia upowszechnił się w I w. po Chr., czego dowodzą m.in. płaskorzeźby nagrobne Marcusa Petroniusa Classicusa Murrucinusa (ryc. 9) i Titusa Calidiusa Severusa. Niestety,

${ }^{80}$ Zob. H. Delbrück, op. cit., s. 380; J. Kromayer, G. Veith, op. cit., s. 309; T. Yoshimura, Die Auxiliartruppen und die Provinzialklientel in der römischen Republik, "Historia” 1961, t. 10, s. 473-475; J. Harmand, op. cit., s. 47-49; K. R. Dixon, P. Southern, The Roman Cavalry, London-New York 1997, s. 22; J. B. McCall, The Cavalry of the Roman Republic, London-New York 2002, s. 1-10.

${ }^{81}$ Suet., Gramm., 9; Plut., Pomp., 64.1; App., BC, 2.76.318, 2.78.328; Tab. Her., 2.89-91; C. Nicolet, L'ordre équestre..., Vol. II, s. 962; J. B. McCall, op. cit., s. 101. Por. BAlex., 56.2; Plut., Pomp., 22.4.

${ }^{82}$ M. Feugère, Weapons of the Romans, przeł. D. G. Smith, Stroud 2002, s. 94-96; M. C. Bishop, J. C. N. Coulston, op. cit., s. 101; R. D'Amato, G. Sumner, op. cit., s. 109-111, 122128; H. Travis, J. Travis, Roman Body Armour, Stroud 2012, s. 90, 94; idem, Roman Helmets, s. 53-56. Z uwagi na wysoką cenę pancerz torsowy był stosowany przez przedstawicieli korpusu oficerskiego oraz bogatszych centurionów. 
nie wiadomo, kiedy powstał usus w tym zakresie i do jakiego stopnia był on rozpowszechniony. Należy zachować daleko idącą ostrożność, jeśli chodzi o przypisywanie tej innowacji żołnierzom republikańskim ${ }^{83}$, ponieważ długotrwałe wojny domowe zazwyczaj nie sprzyjają zmianom o charakterze czysto dekoracyjnym, a poza tym datacja monumentu z Glanum jest zbyt mało precyzyjna.

D'Amato przedstawił niezwykle frapująca teorię, jakoby symbol Gorgony był typowy dla korpusu centurionów ${ }^{84}$. Doprawdy zaskakiwać może, jak często pojawiał się on w tym kontekście. Na tej podstawie włoski badacz jako centuriona zakwalifikował jednego z żołnierzy wyobrażonych na łuku triumfalnym z Arausio (współ. Orange; ryc. 10) ${ }^{85}$. Posiada

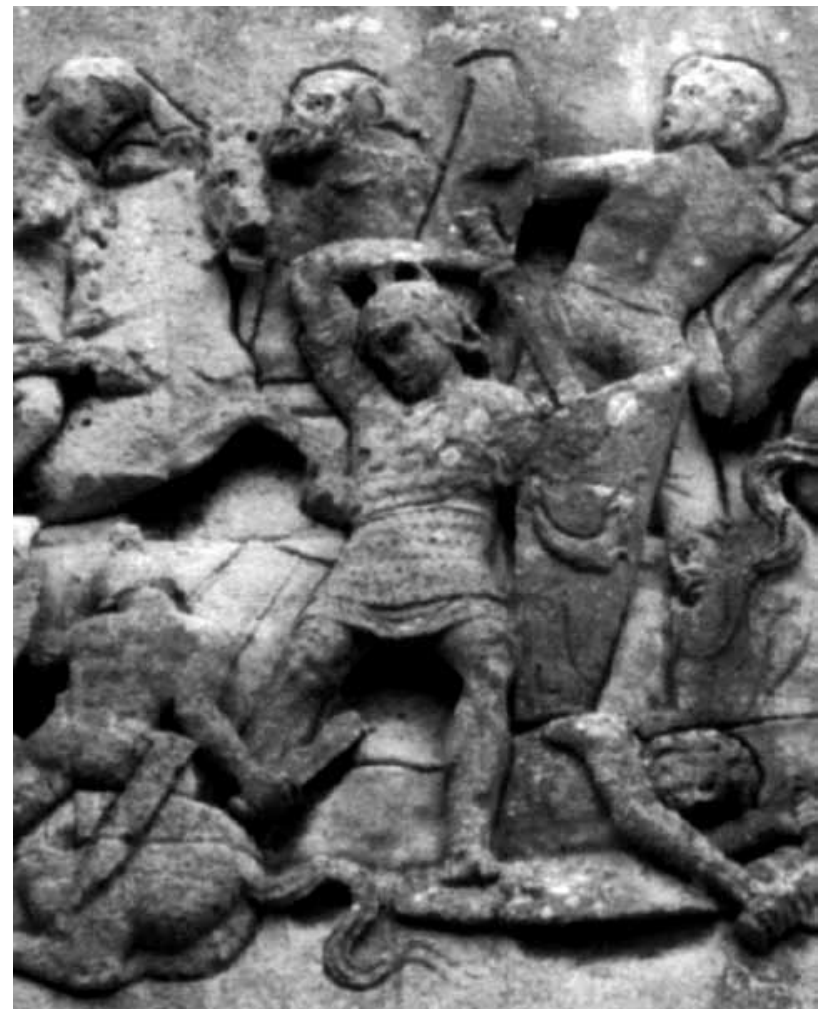

Ryc. 10. Fragment łuku z Arausio (Orange; źródło: R. D'Amato, G. Sumner, Arms and Armour of the Imperial Roman Soldier. From Marius to Commodus, 112 BC-AD 192, London 2009, s. 16) on na piersi dekorację w postaci głowy Gorgony, lecz jest to jedyny element, który może wskazywać na bycie przez niego centurionem. Taka interpretacja, choć na pierwszy rzut oka może wydawać się mocno arbitralna, jest jednak możliwa do obrony. Żołnierz ten posiada bowiem hełm ozdobiony grzebieniem, który nie jest wprawdzie zamocowany w poprzek dzwonu, ale na tle wyposażenia pozostałych zbrojnych widniejących na łuku jawi się jako stosunkowo okazały. Nie jest to oficer, gdyż walczy w samym środku bitwy, posługując się legionowym scutum. Oficerowie korzystali

\footnotetext{
${ }^{83}$ R. D'Amato, Roman Centurions 753-31 BC..., s. 35, 46.

${ }^{84}$ R. D'Amato, Roman Centurions 31 BC-AD 500..., s. 4, 23, 41, 44.

${ }^{85}$ Ibidem, s. 3.
} 
zaś co do zasady z tarczy owalnej (parma) ${ }^{86}$. Dla okresu cesarstwa bardzo trudno zresztą odnaleźć przedstawiciela wyższej kadry dowódczej, który zostałby ukazany podczas walki wręcz, a nie komenderowania żołnierzami $^{87}$. Wszystko to sprawia, że identyfikacja dokonana przez D'Amato wydaje się prawdopodobna.

Problem polega natomiast na ustaleniu, jakie wydarzenie upamiętnia ów łuk i kiedy został wzniesiony. Mogłoby się wydawać, że - tak jak w przypadku łuku z Glanum - nawiązuje on do podboju Galii przez Cezara, nawet jeśli powstał w I w. po $\mathrm{Chr}^{88} \mathrm{Na}$ tarczy centuriona można jednak dostrzec koziorożca, będącego symbolem legio II Augusta ${ }^{89}$. Rzecz w tym, że legion ten nigdy nie służył na terenie Galiii ${ }^{90}$, a jego weterani nie otrzymali tam ziemi - nadano ją za to byłym żołnierzom legio II Gallica, która to jednostka mogła być protoplastką legio II Augusta, szczególnie że po zakończeniu służby wojskowej otrzymała ziemię właśnie w Arausio ${ }^{91}$. Albo więc symbol ten był już stosowany przez legio II Gallica, albo artyście wcale nie chodziło o bezpośrednie związki z legio II Augusta. Koziorożec był symbolem ściśle kojarzonym z Augustem ${ }^{92}$, mogło więc chodzić po prostu o nawiązanie do cesarza. Każe to zadać pytanie, jakie wydarzenie pragnęli zatem uwiecznić fundatorzy? Przeciwnicy Rzymian zostali ukazani jako stereotypowi, długobrodzi barbarzyńcy, nieposiadający żadnych cech szczególnych pomocnych $\mathrm{w}$ ich identyfikacji ${ }^{33}$. Sprawia to, że nie mamy pewności, czy chodziło o późnorepublikańskiego centuriona, nawet jeśli jego wygląd został dostosowany do późniejszych realiów. Wypada więc jedynie poprzestać na uwadze, że sposób umocowania grzebienia - o ile w ogóle można zakładać wierność przedstawienia - nie zawsze musiał

\footnotetext{
${ }^{86}$ Varr., DLL, 5.115; Hor., Car., 2.7.10; R. D'Amato, G. Sumner, op. cit., s. 29.

${ }^{87}$ Według mojej wiedzy takie przedstawienie nie istnieje, jednakże nie można wykluczyć, że któreś z wyobrażeń po prostu nie jest mi znane.

${ }^{88}$ G. Ch. Picard, op. cit., s. 195-198; R. Amy et al., L'Arc d'Orange, XVe supplément à „Gallia”, Paris 1962.

${ }^{89}$ H. M. D. Parker, The Roman Legions, s. 262, 263; G. Webster, op. cit., s. 136; R. D' Amato, G. Sumner, op. cit., s. 15; R. D'Amato, Roman Centurions 31 BC-AD 500..., s. 3, 44; H. Travis, J. Travis, Roman Shields, Stroud 2014, s. 87, 88.

${ }^{90}$ H. M. D. Parker, The Roman Legions, s. 264; L. Keppie, The Making of ..., s. 205.

${ }^{91}$ CRAI 1951, 367.

92 H. Bengtson, Kaiser Augustus. Sein Leben und seine Zeit, München 1981, s. 305-306; D. Kienast, Augustus. Prinzeps und Monarch, Darmstadt 1982, s. 183, 199, 317, 440; T. Barton, Augustus and Capricorn. Astrological polyvalency and imperial rhetoric, "Journal of Roman Studies" 1895, t. 85, s. 33-51.

${ }^{93}$ Pomimo upływu czasu najlepszą pracą na ten temat $\mathrm{w}$ dalszym ciągu pozostaje: P. von Bieńkowski, Les Celtes dans les arts mineurs grèco-romains avec des recherches iconographique sur quelques autres peuples barbares, Cracovie 1928. Jej zakres tematyczny jest znacznie szerszy, niż zdaje się to sugerować tytuł.
} 
być poprzeczny, zaś wyeksponowanie centuriona na pierwszym planie wskazuje na przypisywanie tej kategorii żołnierzy wyjątkowej dzielności i waleczności.

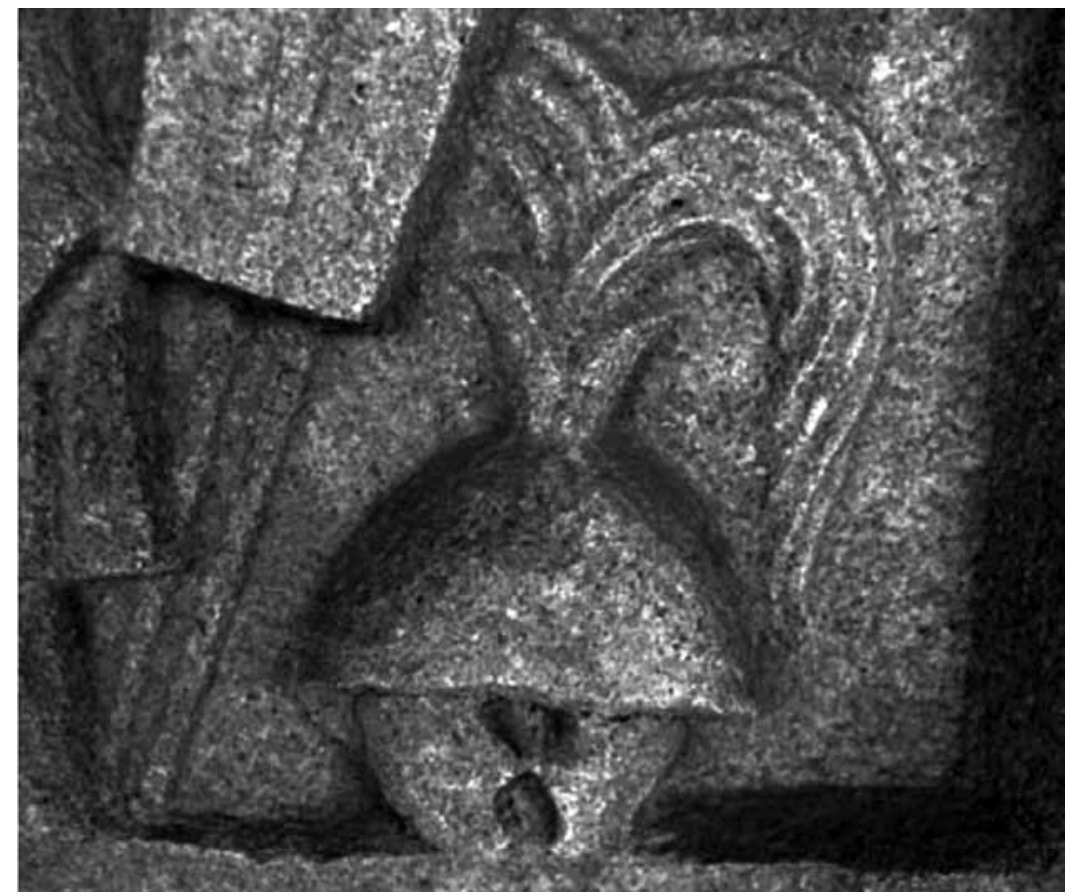

Ryc. 11. Fragment monumentu z Akwilei (ze zbiorów Museo Archeologico Nazionale, Aquileia; źródło: R. D'Amato, Roman Centurions 753-31 BC. The Kingdom and the Age of Consuls, Oxford 2011, s. 15)

Ostatni relief, który może być związany z centurionami, pochodzi z bardzo mocno uszkodzonego monumentu z Akwilei, prawdopodobnie upamiętniającego Cezara kwaterującego tu wraz z armią w 58 r. ${ }^{94} \mathrm{Na}$ podstawie zachowanych fragmentów nie jest możliwe odtworzenie jego wyglądu, natomiast wśród kilku zachowanych przedstawień rzymskiego uzbrojenia znalazł się hełm z crista transversa (ryc. 11). Niekoniecznie musi to być jednak hełm centuriona, o czym świadczy tzw. ołtarz Sulli z Campidoglio, na którym tego typu hełmy zostały ukazane w odmiennym kontekście.

Sumując, zachowane wyobrażenia późnorepublikańskich centurionów, pomimo ich niewielkiej liczby, wzbogacają współczesną wiedzę na temat armii rzymskiej z I w. o następujące wnioski:

${ }^{94}$ R. D'Amato, G. Sumner, op. cit., s. 30. 
1. Jedyne zachowane płaskorzeźby nagrobne o charakterze militarnym dotyczą właśnie centurionów ${ }^{95}$, co jednoznacznie wskazuje na ich wysoki status społeczno-majątkowy. Znamienne jest także, że spośród żołnierzy mobilizowanych na zasadzie dilectus tylko oni definiowali się poprzez służbę w armii, która była przecież częścią rzeczywistości wspólną dla większości pełnoletnich obywateli płci męskiej. Pod tym względem dysponujemy analogią do czasów panowania Augusta i Tyberiusza, z których także znamy głównie płaskorzeźby nagrobne centurionów. Wynikało to prawdopodobnie z kosztów ich sporządzenia, przekraczających możliwości finansowe żołnierzy niższych rangą. Fakt, że to właśnie centurionowie przed wprowadzeniem przez Augusta armii zawodowej manifestowali swoje niegdysiejsze związki z armią, musiał wynikać nie tylko z tego, że to jej zawdzięczali awans społeczny i zgromadzony majątek, ale również z okoliczności, iż centurionowie jako grupa cieszyli się wysokim uznaniem współobywateli. Z takim wnioskiem ściśle koresponduje treść zachowanych przekazów literackich oraz inskrypcja upamiętniająca mieszkającego w Kapui byłego centuriona służącego w wojskach Cezara i Augusta - Luciusa Antistiusa Campanusa - który swój centurionat wymienił $\mathrm{w}$ jednym rzędzie ze sprawowanymi funkcjami cywilnymi i aktami euergetyzmu ${ }^{96}$.

2. Umieszczenie postaci stylizowanych na centurionów na nagrobku Bassusa i łuku z Arausio wskazuje na utożsamianie w I w. centurionów $\mathrm{z}$ archetypem dzielnego żołnierza, co zresztą nie dziwi, zważywszy na zabiegi literackie Cezara i Liwiusza. Być może gdyby z owego okresu zachowało się więcej dzieł tego typu, to nie uważano by obecnie dzieł Cezara za wyjątkowe w tym zakresie. Bez względu na to, co na ów temat pisali Lucius Cornelius Sisenna czy Valerius Antias, ukazanie centuriona w otoczeniu personifikacji Virtus i Honos jest bardzo wymowne. Wpływ na takie postrzeganie centurionatu miały niewątpliwie kryteria przy-

${ }^{55}$ Wyjątkiem może być wzniesiony w Ostii monument honorujący dobroczyńce miasta, Caiusa Cartiliusa Poplicolę, datowany na lata dwudzieste I w. Umieszczone na nim sceny nawiązujące do bitwy pod Akcjum z 31 r. nie muszą jednak wcale świadczyć o odbyciu przez niego służby wojskowej w armii Cezara Młodszego, gdyż był to motyw powszechnie stosowany za panowania Augusta, częstokroć pozbawiony personalnych konotacji (T. Hölscher, Historische Reliefs, s. 363-369; P. Zanker, August i potęga obrazów, przeł. L. Olszewski, Poznań 1999, s. 88-90).

${ }^{96}$ CIL X 3903. Osobnym, niezwykle interesującym tematem jest udział byłych centurionów w życiu społeczno-politycznym kolonii i municypiów. Choć liczba przekazów źródłowych i inskrypcji odnoszących się do tego zagadnienia w czasach republikańskich jest dalece ograniczona, to i tak umożliwia nakreślenie pewnych ogólnych tendencji dających pełniejsze wyobrażenie na temat centurionatu niż studia ograniczone wyłącznie do militarnego aspektu ich funkcjonowania. 
znawania awansu na to stanowisko, premiujące jednostki wyróżniające się odwagą i charyzmą. Rzymscy obywatele, którzy zostali powołani do armii, zdawali sobie sprawę, czym cechowali się centurionowie, co z jednej strony przekładało się na wspomniany powyżej szacunek społeczny, a z drugiej czyniło zawarty na płaskorzeźbach przekaz czytelnym dla większości Rzymian.

3. Mniejsze znaczenie dla badań nad pierwszowieczną wojskowością rzymską ma sposób przedstawienia uzbrojenia stosowanego przez centurionów, a to dlatego, że jest ono bardzo schematyczne, czego skrajnym przykładem jest panoplium widniejące na nagrobku Vetusa. Pomaga jednak ustalić, w jaki sposób wyglądała crista transversa, gdyż żaden z antycznych autorów nie pokusił się o jej dokładny opis. Ponad to aby postać centuriona mogła być rozpoznana przez widza, bez względu na jego przynależność do danej grupy społecznej, rzeźbiarze musieli się posługiwać symbolami tradycyjnie utożsamianymi w I w. z tą kategorią milites. Na tej podstawie, jak również poprzez analogie z okresem wczesnocesarskim, można wysnuć wniosek, że owymi symbolami były rózga oraz crista transversa. Co ciekawe, zarówno w przypadku płaskorzeźby nagrobnej Lorariusa, jak i Vetusa rózgi mają dość specyficzny kształt, sugerujący małą dbałość o detale ze strony osób odpowiedzialnych za ich przedstawienie.

4. Formy wizualne, podobnie jak inskrypcje, dostarczają ważnych informacji na temat konkretnych karier, w tym przypadku Lorariusa i Vetusa. Pierwszy z wymienionych został ukazany z ekwickim pierścieniem na palcu, pomimo tego, że służył w legio vernacula (legio Martia), którego żołnierze - zgodnie $\mathrm{z}$ twierdzeniem Appianosa - nie posiadali $\mathrm{w}$ chwili rozpoczęcia służby obywatelstwa rzymskiego. Jego nazwisko nie wskazuje na wysokie pochodzenie społeczne, stąd też służba w armii okazała się dla Lorariusa niezwykle intratnym zajęciem, dzięki któremu wszedł do ordo equester i grona lokalnej elity. Podobnie do kategorii dekurionów został zaliczony Vetus. Zdobienie jego rózgi sugeruje służbę w Egipcie, co przy okazji wspiera niepoparte bezpośrednimi wzmiankami źródłowymi przypuszczenie, że legio IIII Macedonica brała udział w oblężeniu Aleksandrii. Analiza przypadków indywidualnych pozwala na wyciągnięcie szerszych wniosków odnoszących się do całej kategorii centurionów, ale przede wszystkim przypomina, że za dokonaniami często bezimiennych grup żołnierzy stali konkretni ludzie, którzy tworzyli historię swoich jednostek i rodzinnych miejscowości, jakże różną acz nie mniej barwną, niż losy najbardziej znanych postaci kreujących dzieje późnej republiki. 


\section{BIBLIOGRAFIA:}

A Companion to the Roman Army, red. P. Erdkamp, Malden-Oxford-Carlton 2007.

Amy R. et al., L'Arc d'Orange, XVe supplément à "Gallia”, Paris 1962.

Barton T., Augustus and Capricorn. Astrological polyvalency and imperial rhetoric, "Journal of Roman Studies" 1995, t. 85, s. 33-51.

Bengtson H., Kaiser Augustus. Sein Leben und seine Zeit, München 1981.

Bieńkowski von P., Les Celtes dans les arts mineurs grèco-romains avec des recherches iconographique sur quelques autres peuples barbares, Cracovie 1928.

Bishop M. C., Coulston J. C. N., Roman Military Equipment from the Punic Wars to the Fall of Rome, Oxford 2009.

Broughton T. R. S., The Magistrates of the Roman Republic, Vol. II, New York 1952.

Brunaux J. L., Lambot B., Guerre et armement chez les Gaulois (450-52 av. J.-C.), Paris 1987.

Brunt P. A., Italian Manpower 225 B.C.-A.D. 14, Oxford 1971.

Clarke J. R., Art in the lives of ordinary Romans. Visual representation and non-elite viewers in Italy, 100 B.C.-A.D. 315, Berkeley-Los Angeles 2003.

Cosme P., La remise du cep de vigne au centurion, signe d'appartenance à une élite militaire, [w:] Actes du Colloque: Les élites et leurs facettes. Les élites locales dans le monde hellénistique et romain, red. M. Cébeillac-Gerrasoni, L. Lamoune, Rome-Clermont-Ferrand 2003, s. 339-348.

Cowan R., For the Glory of Rome. A History of Warriors and Warfare, London 2007.

Cowan R., Wojny, bitwy i wojownicy rzymscy, przeł. E. Westwalewicz-Mogilska, Warszawa 2010.

Crawford M. H., Roman Republican Coinage, Vol. I-II, Cambridge 1974.

D'Amato R., Roman Centurions 753-31 BC. The Kingdom and the Age of Consuls, Oxford 2011.

D'Amato R., Roman Centurions 31 BC-AD 500. The Classical and Late Empire, Oxford 2012.

D'Amato R., Sumner G., Arms and Armour of the Imperial Roman Soldier. From Marius to Commodus, 112 BC-AD 192, London 2009.

Delbrück H., Geschichte der Kriegskunst im Rahmen der politischen Geschichte, Bd. I. Das Altertum, Berlin 1920.

Deyber A., Les Gaulois en guerre. Stratégies, tactiques et techniques, Paris 2009.

Dixon K. R., Southern P., The Roman Cavalry, London-New York 1997.

Domaszewski von A., Die Rangordnung des Römischen Heeres, red. B. Dobson, Cologne 1967.

Durry M., Note sur la tenue des centurions (la crista transversa), „Revue Archéologique” 1928, t. 27, s. 303-308.

Eckstein A. M., Senate and General: Individual Decision-making and Roman Foreign Relations, 264-194 B.C., Berkeley-Los Angeles 1987.

Faszcza M. N., Wzrost dyscyplinarnych uprawnień centurionów w I w. p.n.e., [w:] Armia i systemy obronne w Imperium Rzymskim, red. H. Kowalski, P. Madejski, Lublin 2015, s. 11-25.

Faszcza M. N., Vitis centurionis, czyli o okolicznościach nadania centurionom symbolu ich rangi, „Przegląd Historyczno-Wojskowy” 2015, t. 2, s. 7-17.

Feugère M., Weapons of the Romans, przeł. D.G. Smith, Stroud 2002.

Fischer-Bovet Ch., Army and Society in Ptolemaic Egypt, Cambridge 2014.

Forni G., Il reclutamento delle legioni da Augusto a Diocleziano, Milano-Roma 1953.

Gabba E., Republican Rome, the Army \& the Allies, przeł. P.J. Cuff, Oxford 1976.

Goldsworthy A. K., Roman Warfare, London 2000.

Goldsworthy A. K., The Complete Roman Army, London 2003.

Goldsworthy A. K., The Roman Army at War 100 BC-AD 200, Oxford 1996.

Harmand J., L'armée et le soldat à Rome: de 107 à 50 avant notre ère, Paris 1967. 
Harris W. V., War and Imperialism in Republican Rome 327-70 B.C., Oxford 1979.

Hope V. M., Trophies and Tombstones: Commemorating the Roman Soldier, „World Archeology" 2003, t. 35, 1, The Social Commemoration of Warfare, s. 79-97.

Hornblower S., Stick, stones, and Spartans: the sociology of Spartan violence, [w:] War and Violence in Ancient Greece, red. H. van Wees, London-Swansea 2000, s. 57-82.

Hoyos D., Mastering the West. Rome and Carthage at War, Oxford 2015.

Hölscher T., Historische Reliefs, [w:] Kaiser Augustus und die verlorene Republik, red. W. D. Heilmeyer, E. La Roca, E. Künzl, Mainz 1988, s. 351-400.

Hölscher T., Sztuka rzymska: język obrazowy jako system semantyczny, przeł. L. Olszewski, Poznań 2011.

Keppie L., A centurion of legio Martia at Padova?, „Journal of Roman Military Equipment Studies" 1991, t. 2, s. 115-121.

Keppie L., Colonisation and Veteran Settlement in Italy, 47-14 BC, Rome 1983.

Keppie L., Military service in the Late Republic: the evidence of inscriptions and sculpture, "Journal of Roman Military Equipment Studies" 1997, t. 8, s. 3-11.

Keppie L., The Making of the Roman Army. From Republic to Empire, London 1984.

Kienast D., Augustus. Prinzeps und Monarch, Darmstadt 1982.

Kromayer J., Veith G., Heerwesen und Kriegführung der Griechen und Römer, München 1928.

Le Bohec Y., The Imperial Roman Army, przeł. R. Bate, London-New York 2001.

Lendon J. E., Soldiers $\mathcal{E}$ Ghosts. A History of Battle in Classical Antiquity, New Haven-London 2005.

Maxfield V. A., The Military Decorations of the Roman Army, Berkeley-Los Angeles 1981.

McCall J. B., The Cavalry of the Roman Republic, London-New York 2002.

McDonnell M., Roman Manliness. Virtus and the Roman Republic, Cambridge 2006.

Nicolet C., L'ordre équestre à l'époque républicaine (312-43 av. J.-C.), Vol. I, Paris 1966.

Nicolet C., Obywatel, polityk, [w:] Człowiek Rzymu, red. A. Giardina, przeł. P. Bravo, Warszawa 1997, s. 27-67.

Nicolet C., The World of the Citizen in Republican Rome, przeł. P.S. Falla, Berkeley-Los Angeles 1976.

Osgood J., Caesar's Legacy. Civil War and the Emergence of the Roman Empire, Cambridge 2008.

Parker H. M. D., A Note on the Promotion of the Centurions, "Journal of Roman Studies" 1926, t. 16 , s. $45-52$.

Parker H. M. D., The Roman Legions, New York 1958.

Patterson J., Military organization and social change in the later Roman Republic, [w:] War and Society in the Roman World, red. J. Rich, G. Shipley, London-New York 1993, s. 92-112.

Picard G. Ch., Les Trophées romains. Contribution à l'histoire de la religion et de l'art triomphal de Rome, Paris 1957.

Radin M., The Promotion of Centurions in Caesar's Army, „The Classical Journal” 1915, t. 10, nr 7, s. 300-311.

Rankov B., Military Forces, [w:] The Cambridge History of Greek and Roman Warfare, Vol. II. Rome from the Late Republic to the Late Empire, red. P. Sabin, H. van Wees, M. Whitby, Cambridge 2007, s. 30-75.

Rawson E., The Literary Sources for the Pre-Marian Army, "Papers of the British School at Rome" 1971, t. 39, s. 13-31.

Resch K., Die Freiheit des Feldherrn. Der Handlungsspielram römischer Feldherren, 218-133 v. Chr., Wien-Berlin 2010.

Rich J. W., The Supposed Manpower Shortage of the Later Second Century B.C., "Historia” 1983, t. 32, nr 3, s. 287-331.

Rolland H., L'Arc de Glanum, XXXIe supplément à „Gallia”, Paris 1977. 
Rosenstein N. S., Imperatores Victi: Military Defeat and Aristocractic Competition in the Middle and Late Republic, Berkeley-Los Angeles 1990.

Sabin P., The Face of Roman Battle, "Journal of Roman Studies" 2000, t. 90, s. 1-17.

Russel Robinson H., The Armour of Imperial Rome, London 1975.

Sekunda N., Hellenistic Infantry Reform in the 160's BC, Łódź 2001.

Smith R. E., Service in the Post-Marian Roman Army, Manchester 1958.

Suolahti J., The Junior Officers of the Roman Army in the Republican Period. A Study on Social Structure, Helsinki 1955.

Syme R., The Roman Revolution, Oxford 1939.

Toynbee A. J., Hannibal's Legacy: The Hannibalic War Effects on Roman Life, Vol. II. Rome and Her Neighbours After Hannibal's Exit, Oxford 1965.

Travis H., Travis J., Roman Body Armour, Stroud 2012.

Travis H., Travis J., Roman Helmets, Stroud 2014.

Travis H., Travis J., Roman Shields, Stroud 2014.

Webster G., The Roman Imperial Army of the First and Second Centuries A.D., Norman 1998.

Yoshimura T., Die Auxiliartruppen und die Provinzialklientel in der römischen Republik, „Historia" 1961, t. 10, s. 473-495.

Zanker P., August i potęga obrazów, przeł. L. Olszewski, Poznań 1999.

\section{ABSTRACT:}

Modern scholars focused on the Republican Roman Army usually omit the problem of centurions. As a result they are the last category of the Republican commanders who is not comprehensively described in a separate study. According to the author numerous references preserved in the literary sources can be successfully completed by the visual sources in the form of bas-reliefs. Although to the time before the $1^{\text {st }}$ century B.C. their number is relatively small, they give us some unique information which is hard to find in the ancient literature. All the known images of the Republican centurions refer to the $1^{\text {st }}$ century B.C. which is associated with an increase of their military and socio-economic importance in this period. The bas-reliefs proved that some veterans had defined themselves through the prism of their role in legions. Interestingly, at the end of the Republic this phenomenon characterized only centurions, confirming the opinion of their elite status in the Roman army.

Key words: Roman Army, Centurions, Reliefs, Late Roman Republic

Michał Norbert Faszcza - doktor nauk humanistycznych, adiunkt na Wydziale Historycznym Akademii Humanistycznej im. A. Gieysztora w Pułtusku. Kontakt z autorem: michalfaszcza@o2.pl. 